\title{
Field relations, age, and tectonic setting of metamorphic and plutonic rocks in the Creignish Hills - North Mountain area, southwestern Cape Breton Island, Nova Scotia, Canada
}

\author{
Chris E. White ${ }^{*}$, SANdra M. BarR ${ }^{2}$, Donald W. Davis ${ }^{3}$, David S. SWAnton ${ }^{2}$, \\ John W.F. Ketchum ${ }^{4}$, And Peter H. Reynolds 5 \\ 1. Nova Scotia Department of Natural Resources, Halifax, Nova Scotia B3J 2T9, Canada \\ 2. Department of Earth and Environmental Science, Acadia University, Wolfville, Nova Scotia B4P 2R6, Canada \\ 3. Department of Geology, University of Toronto, 22 Russell St., Toronto, Ontario M5S 3B1, Canada \\ 4. Northwest Territories Geoscience Office, PO Box 1500, 4601-B 52 Avenue, Yellowknife, \\ Northwest Territories X1A 2R3, Canada \\ 5. Department of Earth Sciences, Dalhousie University, Halifax, Nova Scotia B3H 3J5, Canada \\ *Corresponding author <whitece@gov.ns.ca $>$
}

Date received: 11 August 2015 g Date accepted: 01 December 2015

\begin{abstract}
The Creignish Hills and North Mountain areas of southwestern Cape Breton Island consist mostly of Neoproterozoic rocks typical of the Ganderian Bras d'Or terrane. U-Pb ages presented here for detrital zircon in the Blues Brook Formation of the Creignish Hills confirm a depositional age no greater than about $600 \mathrm{Ma}$. Although it is possible that some components of the formation are much older, similarities in rock types and field relations suggest that this is not the case. It is likely that the equivalent Malagawatch Formation of the North Mountain area, as well as high-grade metasedimentary rocks of the Melford Formation and Chuggin Road complex in the Creignish Hills and Lime Hill gneiss complex in the North Mountain area, represent the same or stratigraphically equivalent units as the Blues Brook Formation. The minimum ages of all of these units are constrained by cross-cutting syn- and post-tectonic plutons with ages mostly between 565 and $550 \mathrm{Ma}$, indicating that sediments were deposited, regionally metamorphosed, deformed, and intruded by plutons in less than 40-50 million years. The assemblage of pelitic, psammitic, and carbonate rocks indicates that a passive margin in a tropical climate was quickly changed to an active Andean-type continental margin in which voluminous calcalkaline dioritic to granitic plutons were emplaced. This sedimentary and tectonic history is characteristic of the Bras d'Or terrane and is shared by its likely correlative, the Brookville terrane in southern New Brunswick.
\end{abstract}

\begin{abstract}
RÉSUMÉ
Les secteurs des collines Creignish et du mont North dans le sud-ouest de l'île du Cap-Breton sont principalement constitués de roches néoprotérozoïques typiques du terrane de Ganderian Bras d’Or. Les âges $\mathrm{U}-\mathrm{Pb}$ sur zircon détritique de la formation de Blues Brook des collines Creignish présentés ici confirment une sédimentation survenue il y a au plus $600 \mathrm{Ma}$ environ. Même s'il est possible que certains éléments de la formation soient beaucoup plus âgés, les similarités des lithotypes et les observations sur le terrain laissent supposer que ce n'est pas le cas. Il est probable que la formation équivalente de Malagawatch dans le secteur du mont North de même que les roches métasédimentaires à forte teneur de la formation de Melford et du complexe du chemin Chuggin dans les collines Creignish et le complexe de gneiss de la colline Lime dans le secteur du mont North représentent les mêmes unités que la formation de Blues Brook ou des unités stratigraphiquement équivalentes. Les âges minimaux de toutes ces unités sont limités par les plutons
\end{abstract}


syntectoniques et post-tectoniques transversaux, âgés pour la plupart de 550 à $565 \mathrm{Ma}$, ce qui révèle que les sédiments se sont déposés, se sont métamorphisés et déformés à l'échelle régionale, et ont été pénétrés par les plutons au cours d'une période de moins de 40 à 50 millions d'années. Lassemblage de roches pélitiques, psammitiques et carbonatées signale qu'une marge passive dans un climat tropical s'est rapidement transformée en une marge continentale de type andéen active dans laquelle de volumineux plutons calco-alcalins dioritiques à granitiques se sont mis en place. Un tel passé sédimentaire et tectonique est caractéristique du terrane de Bras d'Or et constitue un trait que le terrane a en commun avec l'unité vraisemblablement corrélative du terrane de Brookville dans le sud du Nouveau-Brunswick.

[Traduit par la redaction]

\section{INTRODUCTION}

The Creignish Hills and North Mountain areas of western Cape Breton Island (Fig. 1) consist mostly of Neoproterozoic metasedimentary and plutonic rocks typical of the Bras d'Or terrane of Barr and Raeside (1989) and Raeside and Barr (1990). These areas have been mapped and studied by numerous workers over the years (e.g., Kelly 1967; Milligan 1970; White et al. 1990; Campbell 1990; Justino 1991; Lynch and Brisson 1996; Keppie et al. 1998a; White et al. 2003; Wessel et al. 2005), and the resulting interpretations are varied, hampered by complex field relations and limited age constraints. White and Boehner (2008) compiled and evaluated existing data to produce a revised 1:50 000-scale geological map of the Whycocomagh NTS sheet, and Swanton et al. (2010) extended the mapping to the northeast to include metamorphic and plutonic rocks in the Lewis Mountain-Aberdeen Ridge area (Fig. 2).

The purpose of this paper is to provide an overview of the pre-Devonian geology based on these maps, and to present a new detrital zircon age spectrum from a metasedimentary unit in the Creignish Hills which better constrains the age of the metamorphic units in the area. We also take the opportunity to publish the full database for $\mathrm{U}-\mathrm{Pb}$ zircon ages from the area reported only in preliminary form by White et al. (2003), and to present previously unpublished total fusion ${ }^{40} \mathrm{Ar} /{ }^{39} \mathrm{Ar}$ ages for muscovite from a metasedimentary unit in the Creignish Hills. In addition, we re-examine chemical data from Neoproterozoic plutons in these areas in the light of the current age information, and propose revised names for some of the rock units in the area based on all of the currently available data.

\section{GEOLOGICAL SETTING}

The Bras d'Or terrane of central Cape Breton Island is characterized by low- to high-grade metamorphic rocks intruded by abundant plutons of mainly Late Neoproterozoic age (Fig. 1). Barr and Raeside (1989) and Raeside and Barr (1990) documented tectonostratigraphic differences between these characteristic components of the Bras d'Or terrane and rocks of similar age that characterize the Avalonian Mira terrane of southeastern Cape Breton Island. Those differences have been supported by a number of subsequent studies (e.g., Barr et al. 1995, 1998; Potter et al. 2008a, b), and led to the inclusion of the Bras d'Or terrane, along with similar areas in central Newfoundland and southern New Brunswick, in Ganderia by Hibbard et al. (2006). In contrast, a number of other studies have focused on age similarities between rock units in the Bras d'Or and Mira terranes, and have produced alternative models based on the interpretation that these areas were not separate in the Neoproterozoic (e.g., Keppie and Dostal 1998; Keppie et al. 1990, 1998a, 2000).

The boundary between the Bras d'Or and Mira terranes of Barr and Raeside (1989) is placed in Bras d'Or Lake between North Mountain and Sporting Mountain (Fig. 1). It extends to the northeast through the Boisdale Hills where it coincides with a Carboniferous fault system (MacIntosh Brook Georges River). From there it has been postulated to extend across the Cabot Strait to the south coast of Newfoundland (Barr et al. 1998, 2014a; Rogers et al. 2006). To the southwest, the terrane boundary is suggested to be offset at the Strait of Canso by the Canso fault and inferred to follow the western margin of the Creignish Hills (King 2002; Barr et al. 2012).

The northern boundary of the Bras d'Or terrane is assumed to be located north of the Creignish Hills beneath Carboniferous rocks. This interpretation is based on the occurrence southwest of Lake Ainslie of rhyolite and granite similar to those in the Lake Ainslie-Gillanders Mountain area of the Aspy terrane (Barr and Jamieson 1991). To the northeast, the boundary is inferred to followhigh-strain zones through the central Cape Breton Highlands (Fig. 1). However, the relationship between the Bras d'Or and Aspy terranes is uncertain; available evidence suggests that they are linked in a complex basement/cover relationship, and that Bras d'Or terrane "basement" is likely present under Aspy terrane (e.g., Lin 1993, 1995, 2001; Lin et al. 2007; Price et al. 1999).

Traditionally, most metamorphic rocks in the Bras d'Or terrane were termed the George River Series or Group (e.g., Milligan 1970; Keppie 1979). Raeside and Barr (1990) subdivided these rocks into two assemblages based on metamorphic grade: mainly lower grade units collectively termed the George River metamorphic suite and mainly higher grade and typically gneissic units termed the Bras d'Or metamorphic suite. They also proposed local names for components of both of these metamorphic suites in different areas of the terrane because correlations among them could not be verified. Keppie (2000) termed the higher grade units 


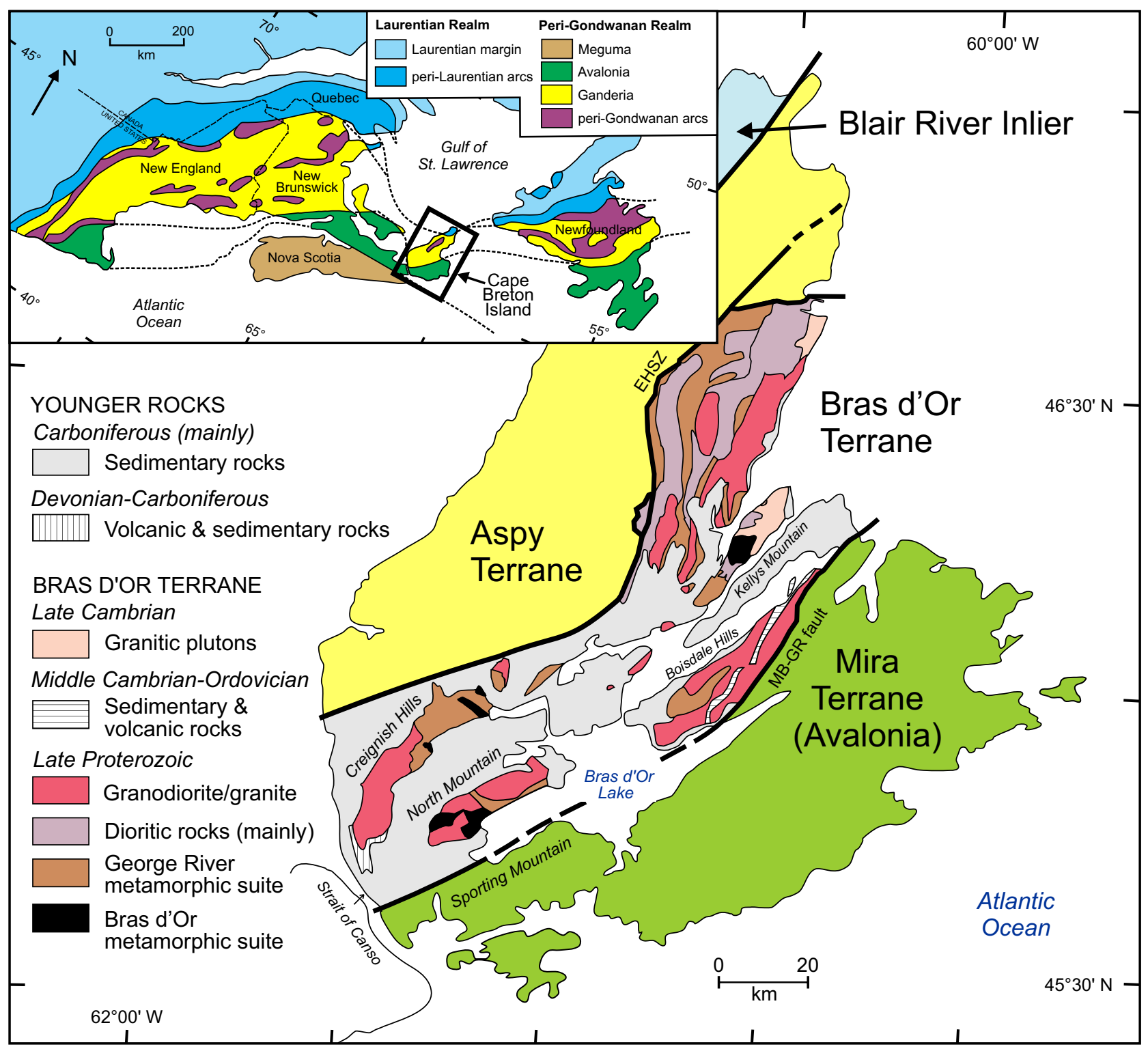

Figure 1. Simplified geological map of the Bras d'Or terrane of central Cape Breton Island after Raeside and Barr (1990) showing the location of the Creignish Hills and North Mountain areas and other areas mentioned in the text. Inset map shows the location of Cape Breton Island in the northern Appalachian orogen with tectonostratigraphic components after Hibbard et al. (2006). Abbreviations: EHSZ, Eastern Highlands Shear Zone; MB-GR fault, MacIntosh Brook - Georges River fault.

the Bras d'Or Gneiss, rather than metamorphic suite, but the latter term is retained here as not all components of the unit are gneissic. Rocks of the George River and Bras d'Or metamorphic suites are everywhere separated from one another by known or inferred faults, or by plutonic units, and hence their relationship is enigmatic. Similarities in rock types suggest that they are the same rocks with different metamorphic histories (e.g., Barr et al. 2013) but even if so, their distribution and geological relations are difficult to explain, as exemplified by the map patterns in Figures 1 and 2 .

\section{GEORGE RIVER METAMORPHIC SUITE IN THE CREIGNISH HILLS - NORTH MOUNTAIN AREAS}

The lower grade (mainly greenschist facies) metamorphic rocks in the Creignish Hills have been named the Blues Brook Formation (Raeside and Barr 1990; Campbell 1990). A compilation of previous work combined with their own mapping led White and Boehner (2008) to divide the Blues Brook Formation into 5 unnamed members, based on dominant rock types (Fig. 2): (1) slate interbedded with 


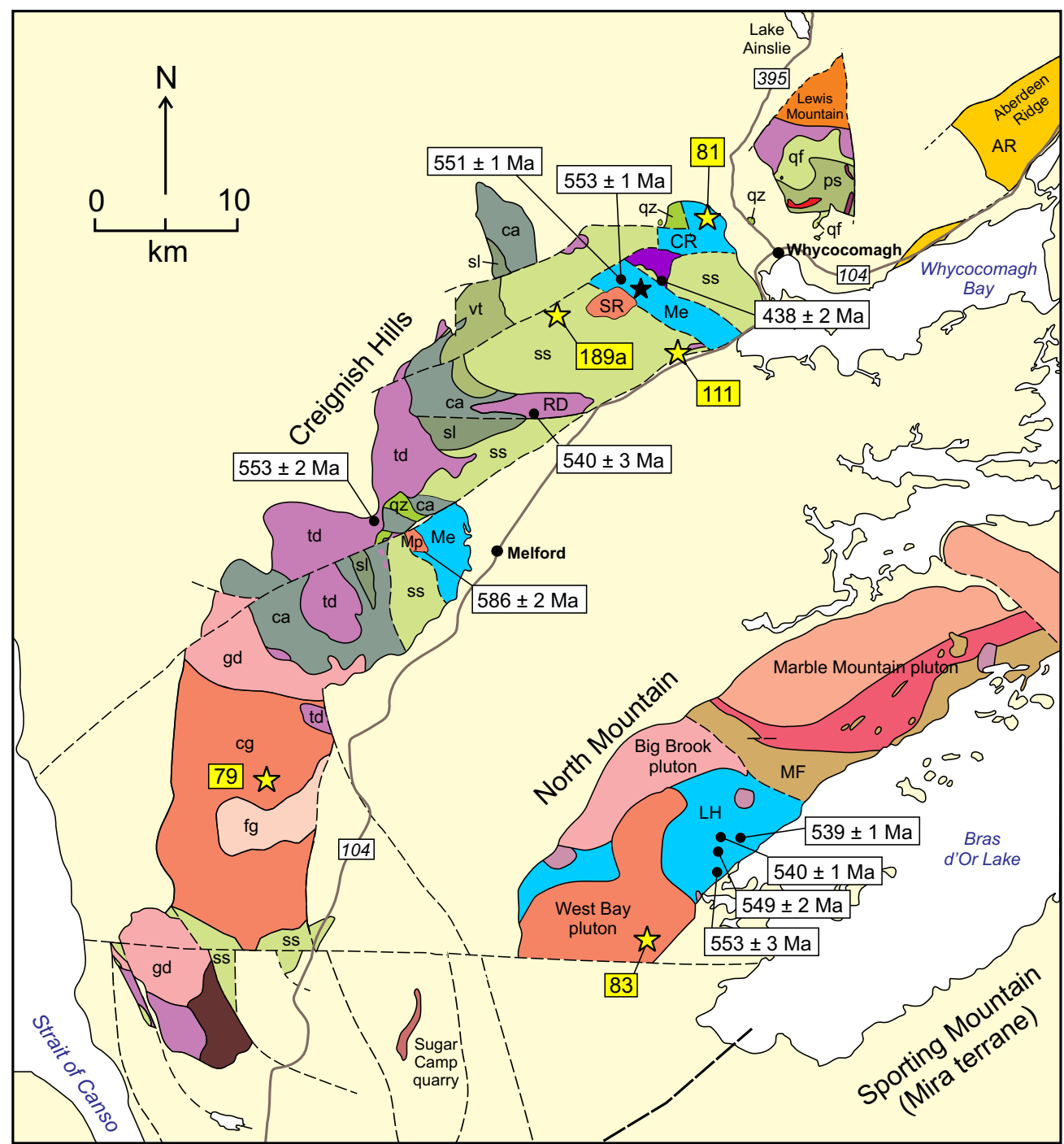

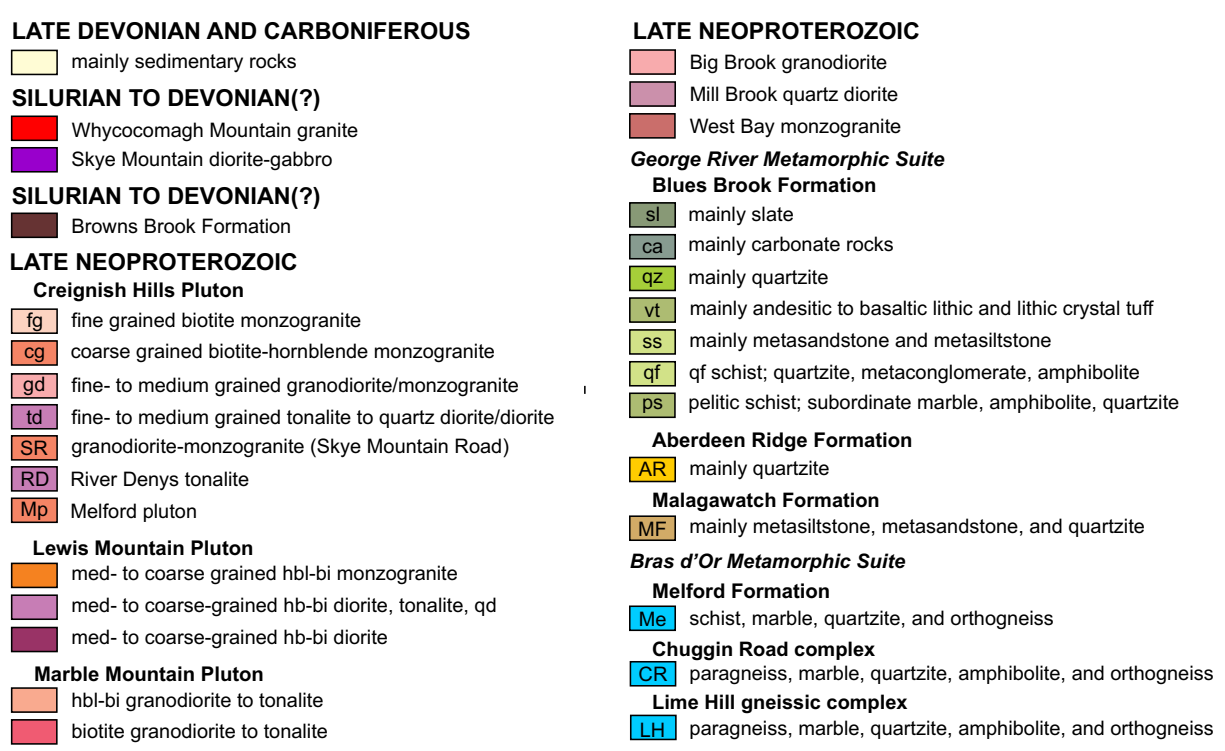

Figure 2. Geological map of the Creignish Hills - North Mountain area after White and Boehner (2008) and Swanton et al. (2010). Geology in the southwestern part of the Creignish Hills and North Mountain areas is modified from Giles et al. (2010). Approximate locations for dated samples are shown as stars. Black star indicates location of a sample that yielded no zircon grains, as described in text. Sources of ages in white boxes are indicated on White and Boehner (2008). 
minor metasandstone, metasiltstone, and metacarbonate rocks (member sl); (2) metacarbonate rock interbedded with minor metasandstone, metasiltstone, slate, and quartzite (member ca); (3) mainly quartzite interbedded with minor metacarbonate rocks (member qz); (4) a volcanic unit consisting mainly of metamorphosed andesitic to basaltic lithic and lithic crystal tuff with minor basalt flows (member vt); and (5) metasandstone and metasiltstone interbedded with minor slate, metacarbonate rocks, quartzite, and rare basaltic lithic tuff (member ss). Similarities in rock types and their map distribution suggest that the members were originally a single stratigraphic succession, although younging directions are poorly preserved and lateral equivalency is possible.

In the extension of the Creignish Hills into the Lewis Mountain - Aberdeen Ridge area to the northeast, Swanton (2010) and Swanton et al. (2010) also recognized the Blues Brook Formation, including a small area of massive white quartzite (member qz; Fig. 2). However, the remaining rocks in the formation in that area could not be readily assigned to any of the other members of White and Boehner (2008) and hence two additional members were identified: member ps, mainly pelitic schist interbedded with subordinate metacarbonate rocks, amphibolite, and quartzite and member qf, quartzofeldspathic schist with quartzite, metaconglomerate, and minor amphibolite (Fig. 2). To the east along the shore of Bras d'Or Lake, Swanton et al. (2010) identified a separate formation, Aberdeen Ridge, which consists of muscovite-chlorite quartzite with minor amphibolite.

In the North Mountain area to the south (Figs. 1, 2 ), the lower grade metamorphic rocks have been named the Malagawatch Formation (Raeside and Barr 1990; Justino 1991). The Malagawatch Formation has not yet been subdivided into members but consists of an assemblage of rock types similar to those of the Blues Brook Formation, including metasiltstone, slate, calcitic and dolomitic marble, calc-silicate rocks, minor quartzite, and mafic metavolcanic rocks (Justino 1991).

Rocks of the Blues Brook Formation are regionally metamorphosed to greenschist facies and grade into lower amphibolite facies in the Whycocomagh Mountain area (Armitage 1989; Campbell 1990; Swanton 2010; Swanton et al. (2010). The metamorphic mineral assemblage in most of the pelitic rocks consists of chlorite, muscovite, biotite, and albitic plagioclase whereas in the Whycocomagh Mountain area the grade is higher and garnet and andalusite are present. Most of the metacarbonate rocks are monomineralic (calcite or dolomite) but locally contain talc, muscovite, phlogopite, garnet, and minor tremolite. In the higher metamorphic grade calc-silicate rocks diopside and forsterite are present (Armitage 1989). The mafic metavolcanic rocks have been metamorphosed to assemblages of actinolite, chlorite, and albitic plagioclase; stilpnomelane has also been reported (Campbell 1990). Contact metamorphic effects are locally well developed around some of the plutonic units and most evident in the pelitic rocks where a hornfelsic texture is preserved containing randomly oriented biotite, cordierite, and rare andalusite.

The protolith age of these metamorphic units is constrained to greater than ca. $586 \mathrm{Ma}$ by dating of mainly undeformed cross-cutting plutons, as described below. However, they have generally been assumed to be much older than 586 $\mathrm{Ma}$, perhaps Mesoproterozoic, based on the presence of stromatolite-like structures in the Malagawatch Formation, similar to those in the Green Head Group of southern New Brunswick which are of inferred Early Proterozoic age (Hofmann 1974; White and Barr 1996; White et al. 2007). This interpretation has been supported by detrital zircon populations that are mainly Archean and Mesoproterozoic in quartzite samples from both areas (Keppie et al. 1998a; Barr et al. 2003). However, a sample of schist from the Blues Brook Formation (Fig. 2) yielded 2 euhedral zircon grains with slightly discordant ${ }^{206} \mathrm{~Pb} /{ }^{238} \mathrm{U}$ ages of $637 \pm$ $3 \mathrm{Ma}$ and $638 \pm 2 \mathrm{Ma}$ (Keppie et al. 1998a). Keppie et al. (1998a) interpreted the schist to have formed from a felsic volcanogenic unit, and the ages to be the age of the igneous protolith. If so, these dates are a maximum age for the Blues Brook Formation and, by inference, other units in the George River metamorphic suite. A younger ${ }^{40} \mathrm{Ar} /{ }^{39} \mathrm{Ar}$ cooling age of $455 \pm 1 \mathrm{Ma}$ was reported for muscovite from the same area (Keppie et al. 2000). Campbell (1990) obtained older muscovite ages of ca. $625 \mathrm{Ma}$ from elsewhere in the same unit, but those data are unpublished and of uncertain reliability.

\section{BRAS D'OR METAMORPHIC SUITE IN THE CREIGNISH HILLS - NORTH MOUNTAIN AREAS}

Keppie (1993), Keppie et al. (1998a), and Wessel et al. (2005) interpreted the presence of a folded shear zone between the low- and high-grade rocks in the Skye Mountain area of the Creignish Hills. They postulated that this shear zone repeatedly intersects the present erosion surface, implying that it is a low-angle tectonic boundary in which the high-grade rocks occur in structural domes. That interpretation was not adopted by White and Boehner (2008), who divided the high-grade metamorphic rocks in the Creignish Hills into two units, one at the northeastern tip for which they used the name Skye Mountain metamorphic suite, and the other, which they termed the Melford Formation, in two areas to the southwest: a fault-bounded block across the trend of the Creignish Hills in the northeast, and a smaller area near Melford in the central part of the Creignish Hills (Fig. 2). This distinction was made because the rocks in the latter two areas are not generally gneissic and differ in rock types from those in the area at the northeastern tip. We here introduce the name Chuggin Road instead of Skye Mountain for the rocks at the northeastern tip of the Creignish Hills because that area is not geographically 
located on Skye Mountain, and furthermore, the name Skye Mountain has long been used for plutonic rocks in the Skye Mountain area (see below). The area of high-grade rocks shown by Armitage (1989), Raeside and Barr (1990), and White and Boehner (2008) on Whycocomagh Mountain was reassigned by Swanton (2010) and Swanton et al. (2010) to the Blues Brook Formation as noted above, based on rock types and metamorphic grade. In the North Mountain area, rocks of the Bras d'Or metamorphic suite are known as the Lime Hill gneissic complex and occur in a large area in the south-central part of North Mountain (Fig. 2).

As described by Raeside (1990), Raeside and Barr (1990), Campbell (1990), and Sangster et al. (1990) the high-grade metamorphic rocks in both the Chuggin Road and Lime Hill units include biotite, bioitite-cordierite, and sillimanite-bearing paragneiss, migmatitic paragneiss, marble, quartzite, amphibolite, and tonalitic orthogneiss. In contrast, the Melford Formation has somewhat different rock types, including biotite, biotite-cordierite, sillimanite, and garnet-bearing schist, marble, quartzite, and granitic orthogneiss (White and Boehner 2008).

Keppie et al. (1998a) provided age constraints on rocks in the Melford Formation of White and Boehner (2008). A muscovite-biotite 'paragneiss' from the southern block yielded mainly mid-Proterozoic ages, but the youngest grain is ca. $977 \mathrm{Ma}$ (Keppie et al. 1998a). A pelitic paragneiss inferred to have a volcanogenic protolith in the fault-bounded block at Skye Mountain yielded zircon grains with ${ }^{206} \mathrm{~Pb} /{ }^{238} \mathrm{U}$ ages between $688 \mathrm{Ma}$ and $694 \mathrm{Ma}$ (Keppie et al. 1998a). These ages were interpreted to be the best estimate of igneous crystallization ages for the inferred volcanogenic protolith. A monazite grain interpreted to be of metamorphic origin in the same sample yielded a concordant age of $552 \pm 8 \mathrm{Ma}$. Farther north and also in the Melford Formation of White and Boehner (2008), a foliated granitic sheet, considered to be syntectonic, yielded two concordant monazite grains with ages of $551 \pm 1 \mathrm{Ma}$, interpreted to be igneous crystallization ages (Keppie et al. 1998a). Two zircon grains yielded discordant but similar ages of ca. $553 \mathrm{Ma}$. These ages provide a minimum age for the Melford Formation. In contrast to these Precambrian ages, ${ }^{40} \mathrm{Ar} /{ }^{39} \mathrm{Ar}$ ages from muscovite in the Melford Formation are younger: 441, 449, 461, 473, and $485 \mathrm{Ma}$ (Campbell 1990; Dallmeyer and Keppie 1993; Keppie et al. 1998a). Similar ${ }^{40} \mathrm{Ar} /{ }^{39} \mathrm{Ar}$ ages were reported for muscovite $(484,524 \mathrm{Ma})$ and biotite $(485 \mathrm{Ma})$ from the area of Melford Formation to the south near Melford (Campbell 1990; Keppie et al. 2000) and muscovite from the Melford pluton (Keppie et al. 2000). An igneous crystallization age of ca. 561 Ma reported by White et al. (2003) for orthogneiss in the Chuggin Road metamorphic suite is described below.

In the case of the Lime Hill gneissic complex, ages are constrained by a concordant $\mathrm{U}-\mathrm{Pb}$ monazite date from paragneiss at $549 \pm 2 \mathrm{Ma}$, and syn- and post-tectonic plutons that yielded discordant $\mathrm{U}-\mathrm{Pb}$ (zircon) data with lower intercepts of $539 \pm 1 \mathrm{Ma}$ and 545-540 Ma (Sangster et al. 1990). An additional constraint is provided by a concordant monazite age of $553 \pm 1 \mathrm{Ma}$ from an anatectic granite sheet in pelitic paragneiss, interpreted to represent the time of peak metamorphism (Keppie et al. 1998a). Keppie et al. (1998a) reported that another monazite grain and rounded zircon grains from the same sheet yielded older but discordant ages.

\section{PLUTONIC ROCKS}

Dioritic to granitic plutons intruded both the low- and high-grade metamorphic units in both the Creignish Hills and North Mountain areas (Fig. 2). White et al. (1990) assigned most of the plutonic rocks in the Creignish Hills area to the Creignish Hills pluton, and subdivided the pluton into five units based on modal mineralogy; texture, and lithogeochemistry: tonalite-diorite, granodiorite-tonalite, granodiorite-monzogranite, coarse-grained monzogranite, and fine-grained monzogranite. This work was done in the early days of geochronological work in Cape Breton Island, and the authors were much influenced by an $\mathrm{Rb}$-Sr isochron using a range of rock types which indicated an age of about $446 \mathrm{Ma}$. However, ${ }^{40} \mathrm{Ar} /{ }^{39} \mathrm{Ar}$ cooling ages of ca. $540 \mathrm{Ma}$ from hornblende in the tonalite - diorite unit indicated a much older minimum age for that body. Furthermore, the granitic components of the pluton had petrological similarities to the Kellys Mountain and Cape Smokey plutons which had yielded U-Pb (zircon) ages of 498 and $493 \mathrm{Ma}$, respectively. Overall, it was concluded based on the available data that the rocks are (questionably) of Ordovician age. Two small plutons in the northeastern part of the belt were together named the Skye Mountain pluton, described as separate bodies of gabbro and granodiorite, and assigned an age anywhere between Precambrian and Carboniferous (White et al. 1990). These plutons were reported to differ from any of the components of the Creignish Hills pluton based on descriptions provided by earlier workers but were not part of the study by White et al. (1990).

Knowledge of the ages of these plutons was much improved as a result of work by Keppie et al. (2000), who reported $\mathrm{U}-\mathrm{Pb}$ (zircon) ages of $553 \pm 2$ for a sample from the largest tonalite-diorite body of the Creignish Hills pluton. This age is consistent with the previously reported ca. $544 \mathrm{Ma}$ hornblende cooling age from that body (Keppie et al. 1990). However, a smaller body of tonalite (River Denys pluton of Keppie et al. 2000) yielded a younger $\mathrm{U}-\mathrm{Pb}$ age of $540 \pm 3 \mathrm{Ma}$, although ${ }^{40} \mathrm{Ar} /{ }^{39} \mathrm{Ar}$ ages for amphibole from the same sample and another sample in the same unit are older (ca. 550 and 551 Ma; Keppie et al. 1990). Keppie et al. (2000) concluded that, overall, these 540-550 Ma ages "post-date closely the time of intrusion", and that the River Denys Pluton is part of the same magmatic event as the $553 \mathrm{Ma}$ diorite of the Creignish Hills pluton. The age of the Creignish Hills pluton was 
further constrained by a ca. $553 \mathrm{Ma}$ age for the main granitic unit reported by White et al. (2003) and presented below.

In contrast to these Neoproterozoic ages, a sample reported to be from the gabbro-diorite body of the Skye Mountain pluton yielded a Silurian age of $438 \pm 2 \mathrm{Ma}$ (Keppie et al. 1998b, 2000). A sample from the separate granitic body to the west yielded only old (ca. $737 \mathrm{Ma}$ ) discordant zircon grains, but Keppie et al. (2000) inferred a Silurian age, based on muscovite plateau ages in the surrounding host rocks, especially an age of $441 \mathrm{Ma}$ from what they interpreted to be the contact metamorphic aureole adjacent to the granite. Keppie et al. (2000) and Wessel et al. (2005) showed the Skye Mountain granite and gabbro-diorite as contiguous bodies on their maps, whereas previous maps (White et al. 1990; Horton 1994) showed them as separate bodies. Horton (1994) interpreted them to be unrelated based on their very different petrographic and chemical characteristics. He considered the foliated granitic sheet in the Melford Formation north of the pluton to be related to the granite and hence its ca. $551 \mathrm{Ma}$ age to be the age of the pluton.

After a re-evaluation of outcrop locations and additional mapping in the area, White and Boenher (2008) confirmed that the two plutons are separated by a belt of rocks of the Melford Formation. They included the western (granitic) pluton in the Creignish Hills pluton, to which it is petrographically similar, and inferred a similar ca. 550 Ma age. Hence, to avoid further confusion, the name Skye Mountain is retained here for only the gabbroic-dioritic body and a new name, Skye Mountain Road, is introduced for the western body, named after the road on which it is best exposed.

The small granitic body termed the Melford pluton by Keppie et al. (2000) yielded an older U-Pb (zircon) age of $586 \pm 2 \mathrm{Ma}$, although this two-point upper intercept age is of limited reliability. The pluton intruded gneissic rocks assigned by Keppie et al. (2000) to the Bras d'Or Gneiss (Melford Formation in this study), and was interpreted to be late syn-tectonic based on the presence of a weak foliation parallel to that in its host rocks. White and Boehner (2008) showed that the pluton is larger than suggested by Keppie et al. (2000), and that it is faulted on its southwestern and northwestern edges against rocks of the Blues Brook Formation. They included the pluton in the granitic unit of the Creignish Hills pluton, in spite of its apparently somewhat older age and the occurrence of muscovite for which Keppie et al. (2000) reported a cooling age of $472 \mathrm{Ma}$. Muscovite is not a typical component of the Creignish Hills granite but has also been reported in part of the Skye Mountain Road pluton (Horton 1994).

Plutons form most of the North Mountain area, and were studied in detail by Justino (1991) and Justino and Barr (1994). Those authors divided the plutonic rocks into the Big Brook and Marble Mountain plutons, of mainly granodiorite composition, and the West Bay Pluton, composed of coarse-grained monzogranite. The latter pluton is cut off by a fault according to the map by Giles et al. (2010) but likely extends south of the fault with minor offset, based on the presence of outcrops of similar granite in the Sugar Camp gypsum quarry (Fig. 2). Small tonalitic to dioritic bodies (Mill Brook quartz diorite and related plutons) occur along the margins of these large plutons. Age constraints are provided by ${ }^{40} \mathrm{Ar} /{ }^{39} \mathrm{Ar}$ hornblende cooling ages of $555 \pm 5 \mathrm{Ma}$ apparently from the Marble Mountain biotite granodiorite unit (based on approximate location shown by Keppie et al. 1990) and $550 \pm 5 \mathrm{Ma}$ and $545 \pm 6$ Ma on two separate bodies of the Mill Brook quartz diorite (Keppie et al. 1990) and the ca. 553 Ma age for the West Bay Granite reported by White et al. (2003) and presented below.

\section{GEOCHRONOLOGY}

\section{Methods}

In this paper we report new detrital zircon ages for a sample (SMB14-189A) collected from the same location as sample $11 \mathrm{Z}$ reported by Keppie et al. (1998a). We resampled this site in order to further investigate the hints of young zircon grains in sample 11Z. The methods and data table are presented in Appendix A. We also resampled at the same location in the Melford Formation as paragneiss sample $188 \mathrm{Z}$ of Keppie et al. (1998a) but the sample yielded no zircon grains suitable for analysis.

We also present the data for the ages published in preliminary form by White et al. (2003). The methods and data tables are presented in Appendix B.

Muscovite was separated from a sample of mica schist interlayered with marble in unit ss near the southern margin of the Creignish Hills (Fig. 2). The analytical method and data are presented in Appendix C (Table C1).

\section{Results}

\section{Sample SMB14-189A}

Sample SMB14-189A from the Blues Brook Formation (UTM coordinates $5090806 \mathrm{~N}, 637216 \mathrm{E}$ ) yielded a small amount of tiny rounded zircon grains. Clear areas on the zircon grains were targeted for analysis so as to avoid cracks. $\mathrm{U}-\mathrm{Pb}$ analyses are all near- concordant (Appendix Table A1) and give a wide range of Neoproterozoic to Archean ages (Fig. 3a). A subset of brownish grains proved to be relatively old, and included the two Archean grains (Table A1). Over half of the grains are grouped into a relatively tight cluster with ${ }^{206} \mathrm{~Pb} /{ }^{238} \mathrm{U}$ ages that vary over the range of about 600-700 Ma (Fig. 3a). Deposition of the unit was therefore at or younger than $600 \mathrm{Ma}$ and much of the detritus in the sample was derived from Neoproterozoic rocks.

\section{Sample SMB02-81}

Sample SMB02-81, collected from an active quarry near Chuggin Road northwest of Whycocomagh (UTM 

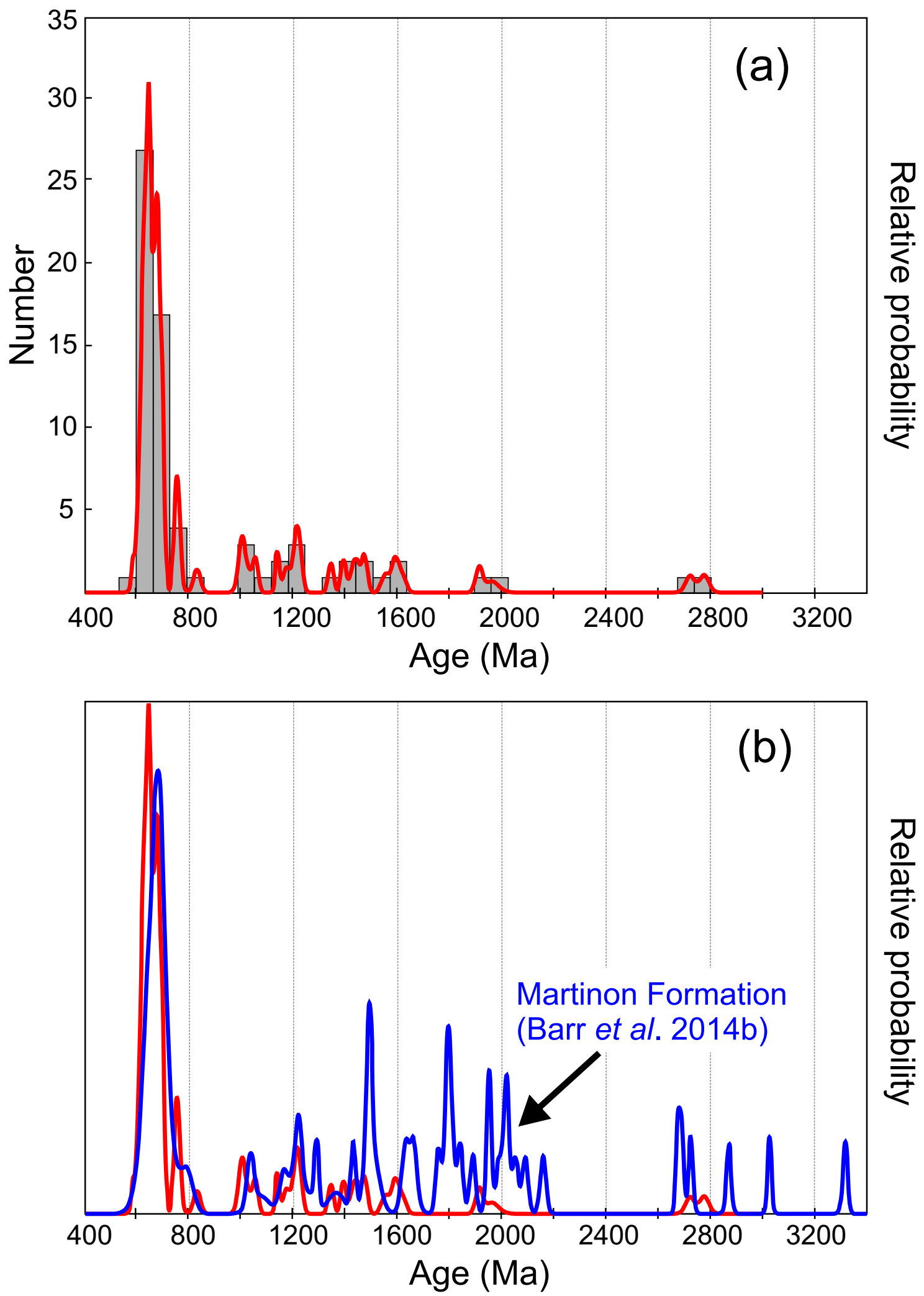

Figure 3. (a) U-Pb concordia diagram and probability plot constructed using Isoplot (Ludwig 2003) for sample SMB14189A. (b) Comparision between the probability plot from (a) and that for the Martinon Formation in the Brookville terrane of southern New Brunswick from Barr et al. (2014b). Methods are described in Appendix A and data are in Table A1. 
coordinates $5094125 \mathrm{~N}, 642350 \mathrm{E}$ ), is a fine- to mediumgrained tonalitic orthogneiss that consists mostly of quartz, plagioclase, and biotite. It is interpreted as an orthogneiss based on its homogeneous appearance in outcrop and on the presence of relict weakly zoned plagioclase grains visible in thin section. A relatively high $\mathrm{Th} / \mathrm{U}$ ratio (mostly $>0.5$ ) in the zircon is also consistent with an igneous origin. The zircon population obtained from the sample is characterized by colourless, good-quality euhedral and subhedral prisms ranging from equant to elongate with length to breadth ratio of 3:1 to 4:1. Many equant grains are distinctly zoned with an apparent euhedral overgrowth component, but this component is not present on most long prisms. Four fractions consisting of long prisms (length:breadth $>3: 1$ ), both with and without tiny fluid inclusions, are concordant or nearconcordant at 565-560 Ma (Fig. 4a; Table B1). Their average ${ }^{207} \mathrm{~Pb} /{ }^{206} \mathrm{~Pb}$ age of $561 \pm 3 \mathrm{Ma}$ is interpreted as the igneous crystallization age of the tonalite, although we acknowledge that a slightly older age of ca. $565 \pm 3 \mathrm{Ma}$ (based on the ${ }^{206} \mathrm{~Pb} /{ }^{238} \mathrm{U}$ age of analysis $\mathrm{Z1}$ ) is possible. Two additional fractions ( 1 and 4 grains each) of equant, colourless grains give discordant results indicating mid-Proterozoic inheritance (Fig. 4a). The age constrains the age of metasedimentary components of the Chuggin Road and other parts of the Bras d'Or metamorphic suite to greater than ca. $565 \mathrm{Ma}$.

\section{Sample SMB02-79}

The Creignish Hills pluton was sampled for dating on a logging road in the south-central part of the Creignish Hills (UTM coordinates $5071750 \mathrm{~N}, 626375 \mathrm{E}$ ). Sample SMB02-79 is typical of the medium- to coarse-grained monzogranitic unit that forms most of the pluton (White et al. 1990). It consists of quartz, K-feldspar (perthitic orthoclase), and plagioclase in approximately equal proportions, with minor biotite and hornblende. It yielded abundant equant to 2:1, euhedral, four-sided zircon prisms of varying size. Fluid inclusions are relatively common and opaque mineral inclusions were also observed. Four concordant or nearconcordant single grain and multigrain fractions (Table B1) have an average ${ }^{207} \mathrm{~Pb} /{ }^{206} \mathrm{~Pb}$ age of $553+/-3 \mathrm{Ma}$ (Fig. $4 \mathrm{~b}$ ) which we interpret as the crystallization age of the granite.

\section{Sample SMB02-83}

The West Bay Granite was sampled in a quarry at the southwestern margin of North Mountain (UTM coordinates $5066850 \mathrm{~N}, 641000 \mathrm{E})$. The dated sample is coarse-grained monzogranite, with $\mathrm{K}$-feldspar megacrysts up to $5 \mathrm{~cm}$ in length. Mafic minerals (biotite and possibly hornblende) have been replaced by chlorite. The zircon population in this sample appears identical to that for sample SMB02-79, and three near-concordant single grain and 2-grain fractions (Table B1) yield an identical crystallization age of $553 \pm 2 \mathrm{Ma}$ (Fig. 4c).

\section{Sample SMB06-111}

Muscovite schist sample SMB06-111 was collected from a
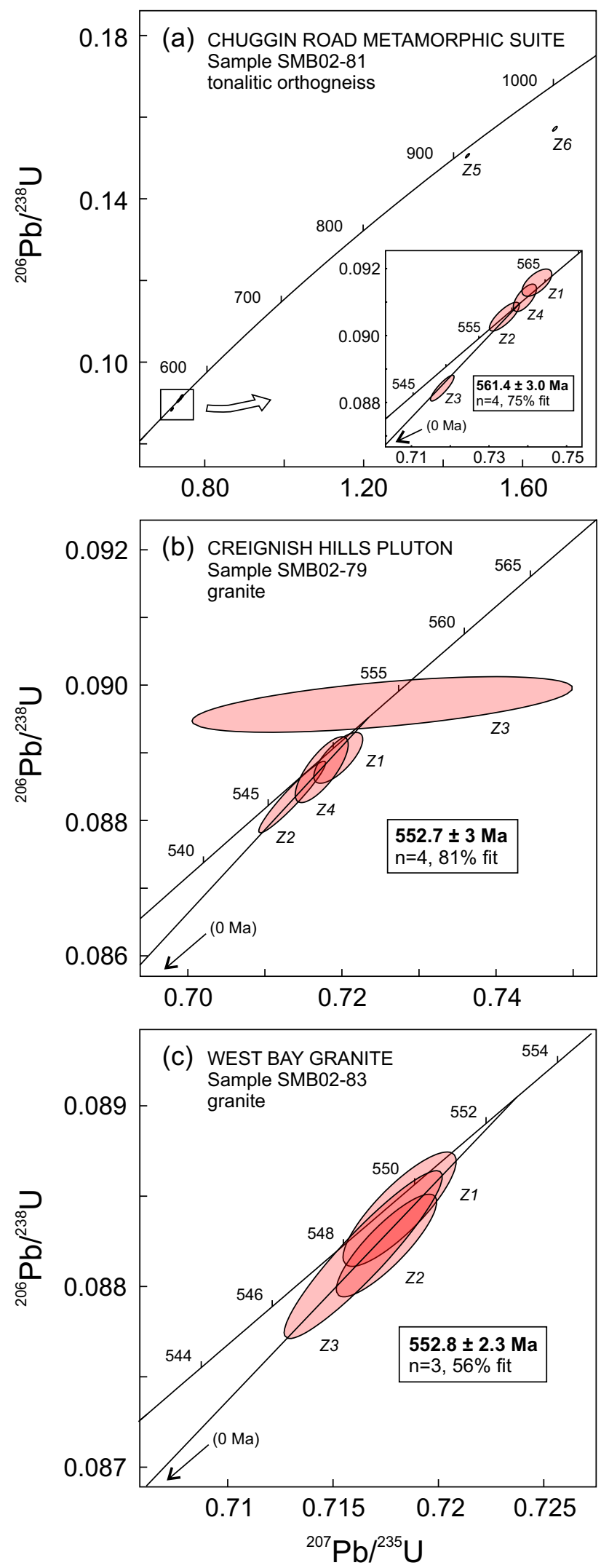

Figure 4. U-Pb Concordia diagrams for metaigneous and igneous samples. Methods are described in Appendix B and data are in Table B1. 
small quarry in the Blues Brook Formation near the faulted southeastern margin of the Creignish Hills (Fig. 2). To reduce the possibility of homogenization of Ar isotopes during traditional incremental heating of muscovite and to reduce any core-rim effect (i.e., intracrystalline age discordance), standard single-grain, laser fusion ${ }^{40} \mathrm{Ar} /{ }^{39} \mathrm{Ar}$ ages were used (e.g., Hames et al. 2008). Hence, each analysis is a mean age of the muscovite grain (Appendix C). Total fusion analyses of 23 single muscovite grains yielded apparent ages ranging from $488 \mathrm{Ma}$ to $430 \mathrm{Ma}$ (Table C1). Displayed on a histogram (Fig. 5), ages cover the range between those high- and low-age cutoffs. The simplest interpretation is that these ages represent partial resetting of older $(>500 \mathrm{Ma})$ muscovite at about $430 \mathrm{Ma}$ (see further discussion below). Because the dated sample is from near the major faulted margin of the Creignish Hills, it is likely that the resetting is a result of deformation (e.g., Mulch and Cosca 2004).

\section{DISCUSSION}

\section{Age of the George River and Bras d'Or metamorphic suites}

Keppie and Dostal (1998) interpreted that the George River metamorphic suite (Blues Brook and Malagawatch formations) in the Creignish Hills and North Mountain areas consists of two parts - an older non-volcanogenic sedimentary package (quartzite, marble, schist, phyllite) and a younger volcanogenic package in which similar rocks are interlayered with felsic volcanogenic rocks and mafic flows. Based on their U-Pb data (summarized above), they estimated depositional ages of $\sim 977-700 \mathrm{Ma}$ and $\sim 694-637$ $\mathrm{Ma}$, respectively, for these two packages. They showed that the mafic volcanic rocks in the inferred younger package are within-plate tholeiite, and attributed them to a backarc basin associated with a volcanic arc of similar age in the Stirling belt of the now-adjacent Avalonian Mira terrane. Our sample from the same location as the sample that yielded the $\sim 694$ and $637 \mathrm{Ma}$ ages contains abundant grains as young as $600 \mathrm{Ma}$, showing that the maximum depositional age for the unit is younger than suggested by the data of Keppie et al. (1998a). These new data are inconsistent with the interpretation made by Keppie and Dostal (1998) that the rocks formed in a back-arc related to the birth of arc magmatism in Avalonia because the main pulse of arc magmatism in many parts of Avalonia, including the now-adjacent Mira terrane, is at about $620 \mathrm{Ma}$ and arcrelated rocks as old as $680 \mathrm{Ma}$ are documented in the Mira terrane (Barr et al. 1996, 1998). These rocks are clearly older than the depositional age of at least part of the Blues Brook and Malagawatch formations. It also makes the chemical characteristics documented by Keppie and Dostal (1998) difficult to interpret, as discussed further in the next section.

Based on field relations and similarities in rock types, it

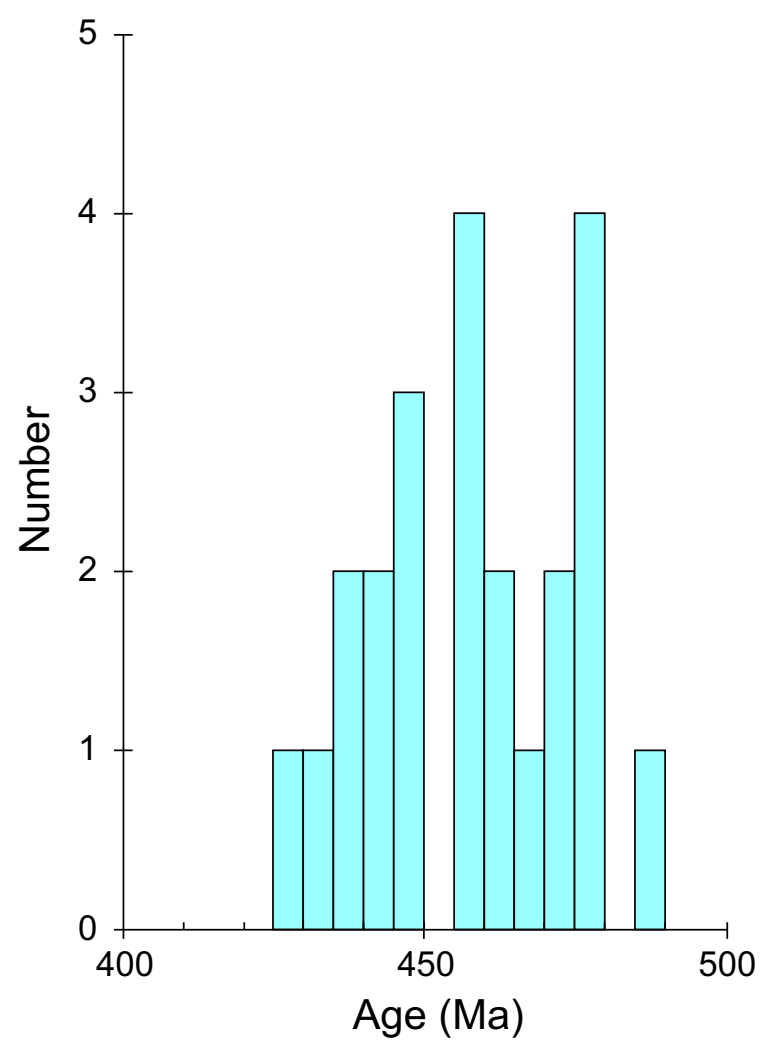

Figure 5. Histogram for single-grain white mica ${ }^{40} \mathrm{Ar} /{ }^{39} \mathrm{Ar}$ total-fusion analyses from sample SMB06-111. Methods are described in Appendix $\mathrm{C}$ and data are in Table C1.

seems unlikely that the components of the Blues Brook and Malagawatch formations are of widely different ages. White and Boehner (2008) interpreted the units to form a single stratigraphic succession. The minimum age is constrained by the abundant plutons with ages of ca. $550 \mathrm{Ma}$ that intruded these rocks. Hence it seems that these sediments were deposited, regionally metamorphosed and deformed, and intruded by abundant plutons in less than 50 million years.

Only sparse detrital zircon data are available from other metasedimentary rocks in the Creignish Hills and Bras d'Or terrane in general (Keppie et al. 1998a; Barr et al. 2003), but a larger database is available from the Brookville terrane of southern New Brunswick. The detrital zircon age signature displayed by sample SMB14-189A is similar, especially in its Late Mesozoic to Neoproterozoic to part, to that of the Martinon Formation in New Brunswick, in which the most abundant zircon grains have ages between 650 and $600 \mathrm{Ma}$, and many fewer grains have ages between $1000 \mathrm{Ma}$ and 2200 Ma (Fig. 3b). Like the Blues Brook Formation, the Martinon Formation is part of the low-grade metasedimentary assemblage in the Brookville terrane, and closely associated with quartzite and marble, which locally contains stromatolite-like structures. Similarity in detrital zircon signatures between the $>1000 \mathrm{Ma}$ grains in the associated quartzite as well as in the high-grade assemblage (Brookville 
Gneiss) in the terrane led Barr et al. (2014b) to conclude that the high- and low-grade rocks are related, although the quartzite and paragneiss age spectra lack the 650-600 Ma zircon grains. Based on the results of Keppie et al. (1998a), the same situation exists in the Creignish Hills, although one sample of paragneiss from the Melford Formation contains grains as young as $688 \mathrm{Ma}$ and $694 \mathrm{Ma}$ (Keppie et al. 1998a). Resampling at that locality for the present study (black star, Fig. 2) did not result in any zircon grains which could have better constrained those younger ages.

The age of ca. $561 \mathrm{Ma}$ from orthogneiss in the Chuggin Road complex (Fig. 4a) provides a minimum age for the Bras d'Or metamorphic suite and a maximum age for regional metamorphism. It is supported by several monazite and zircon ages of ca. 550 Ma reported by Keppie et al. (1998a) and Sangster et al. (1990) from the Creignish Hills and North Mountain areas (Figs. 6a, b). All of these data indicate a major thermal event at that time, coincident with regional metamorphism and widespread magmatic activity as discussed further in the subsequent section.

The assemblage of pelitic, psammitic, and carbonate rocks in the Blues Brook and Malagawatch formations and the likely correlative high-grade units indicates that they formed on a passive margin in a tropical climate, as also inferred for the Brookville terrane in southern New Brunswick (Barr et al. 2014b). Barr et al. (2014b) suggested that this passive margin was located on the Proto-Andean - Caribbean edge of Amazonia after it had separated from Laurentia by ca. $650 \mathrm{Ma}$.

\section{Pluton ages and geochemistry}

The $\mathrm{U}-\mathrm{Pb}$ igneous crystallization ages from zircon and monazite in plutonic rocks ranging from dioritic to granitic in the Creignish Hills and North Mountain areas cluster at about $550 \mathrm{Ma}$ (Fig. 6a). The fact that ${ }^{40} \mathrm{Ar} /{ }^{39} \mathrm{Ar}$ cooling ages from amphibole in these units are similar to the zircon ages (Figs. 6a, b) indicates that these plutons cooled quickly and hence were probably epizonal, as also noted by Keppie et al. (1990) and Dallmeyer and Keppie (1993). In contrast to previous suggestions based on less reliable age estimates (White et al. 1990; Raeside and Barr 1990), the granitic rocks are the same age as the dioritic and tonalitic rocks and did not form in a separate, much younger igneous event.

This interpretation is further supported by chemical characteristics which show coherence among all of the known and inferred Neoproterozoic plutons in the Creignish Hills and North Mountain areas, as illustrated in Figure 7. With the exception of 3 new analyses (Table D1), the chemical data depicted on this figure have been previously published in theses and papers. Hence we are not presenting the data again but include instead a list of sample numbers and data sources (Table D2), as the analyses may not have been identified with the correct age or pluton in the original paper.

As illustrated in Figure 7, the analyses from the Skye Mountain Road pluton (data from Horton 1994) are similar to those from the other granitic and granodioritic plutons, consistent with the interpretation that it is the same ca. $550 \mathrm{Ma}$ age and not Silurian like the Skye Mountain diorite-gabbro. Similarly, the River Denys tonalite is chemically similar to other dioritic and tonalitic components of the Creignish Hills pluton, consistent with the interpretation of Keppie et al. (1998a) that the plutonic rocks are part of a single magmatic episode, even though ages show some variation. No chemical data are available from the possibly older (ca. $586 \mathrm{Ma}$ ) Melford pluton to indicate whether or not it is chemically similar to the other plutons, but White and Boehner (2008) correlated it with the coarse-grained granitic unit of the Creignish Hills pluton based on petrographic features.

With an igneous crystallization age of ca. $561 \mathrm{Ma}$, the tonalitic orthogneiss in the Chuggin Road metamorphic suite is also slightly older than the dominant ca. $550 \mathrm{Ma}$ plutons of the Creignish Hills - North Mountain area, but dioritic, tonalitic, and granodioritic plutons elsewhere in the Bras d'Or terrane have yielded U-Pb (zircon) crystallization ages as old as $565 \mathrm{Ma}$ (Fig. 6a). The Chuggin Road orthogneiss sample has chemical characteristics that are generally similar to other plutonic samples with similar silica content, but it has higher $\mathrm{CaO}$ and hence plots somewhat separately in terms of normative mineralogy (Fig. 7e).

Overall, samples from all of the plutons show the range of compositions typical of I-type granitoid suites (Fig. 7). They lie on a calc-alkalic trend on an AFM diagram (Fig. $8 \mathrm{a})$, and range from metaluminous in the more mafic samples to peraluminous in the felsic samples (Fig. 8b). They have trace element characteristics of volcanic-arc granites, evolving toward within-plate characteristics in the most felsic (evolved) samples (Fig. 8c). These characteristics are shared by Neoproterozoic plutons throughout the Bras d'Or terrane (e.g., Farrow and Barr 1992; Raeside and Barr 1990; Grecco and Barr 1999; Wasylik et al. 2005; Swanton 2010). It is clear that a huge volume of plutonic rocks was emplaced in the Bras d'Or terrane mainly between about 565-550 Ma and that they formed in an Andeantype continental margin subduction zone. A similar interpretation has been made for the Brookville terrane of southern New Brunswick, although the pluton ages there are overall younger at 550-525 Ma (White et al. 2002).

\section{Significance of muscovite ages}

As noted above, ${ }^{40} \mathrm{Ar} /{ }^{39} \mathrm{Ar}$ cooling ages from muscovite in both plutonic and metamorphic rocks of the Creignish Hills are younger than most of the pluton crystallization ages, whereas the hornblende ages reflect pluton cooling at ca. 550-540 Ma (Figs. 6a, b). Examining the geographic distribution of the muscovite ages reported by Dallmeyer and Keppie (1993) from the Creignish Hills, most if not all samples are from proximity to the major shear zones which cross the area. The sample dated in the present study is from near the faulted southeastern margin of the Blues 

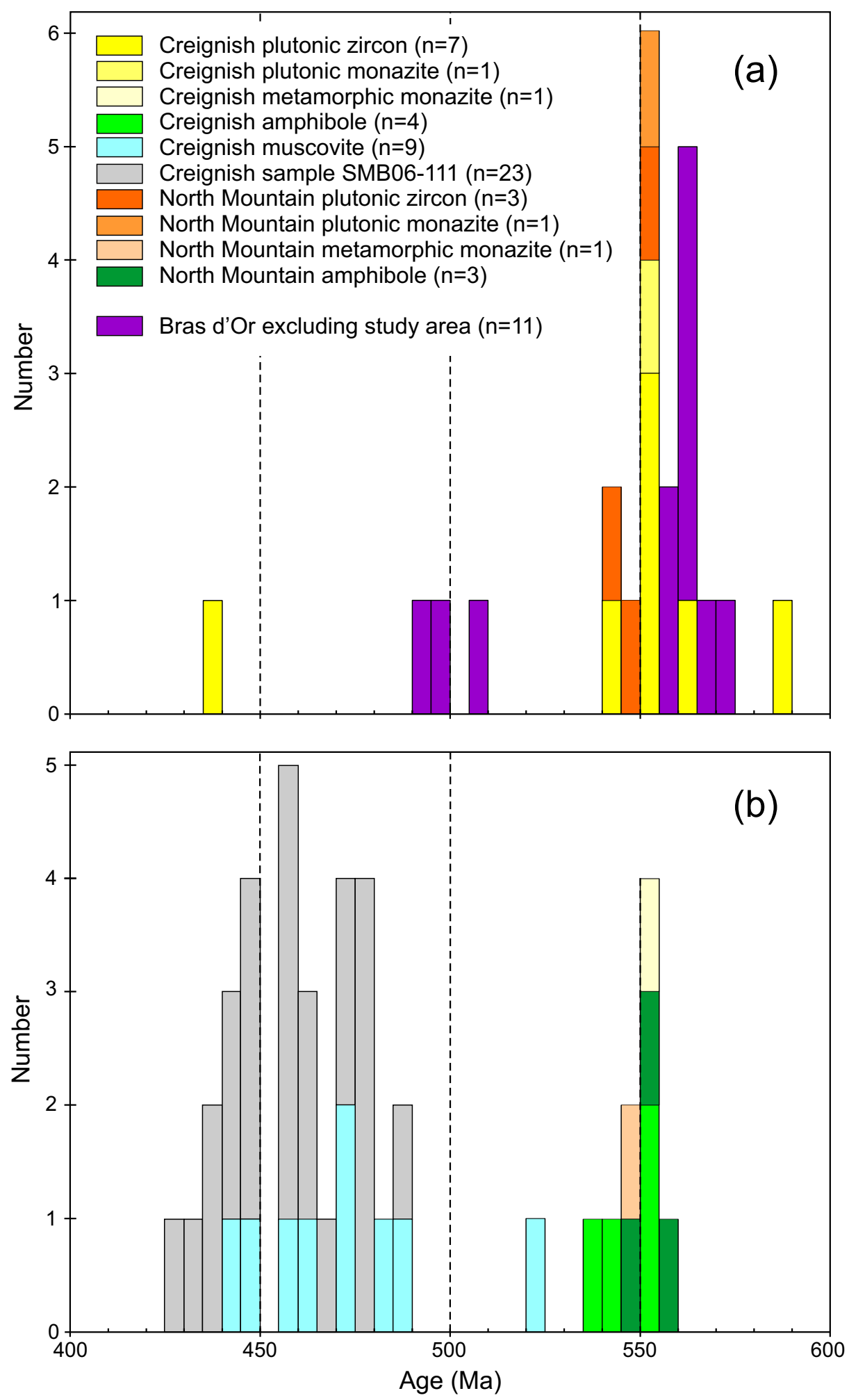

Figure 6. Histograms summarizing (a) U-Pb zircon and U-Pb monazite ages interpreted as igneous crystallization ages for plutonic units in the Creignish Hills and North Mountain areas and (b) ${ }^{40} \mathrm{Ar} /{ }^{39} \mathrm{Ar}$ muscovite and hornblende ages from igneous and metamorphic units and $\mathrm{U}-\mathrm{Pb}$ (monazite) ages interpreted to be metamorphic ages as described in the text. $\mathrm{U}-\mathrm{Pb}$ (zircon) igneous crystallization ages from other plutonic units in the Bras d'Or terrane (Cape Smokey granite, Kellys Mountain granite, Cameron Mountain syenogranite, Ingonish River tonalite, Gisborne Flowage quartz diorite, Birch Plain granite, Indian Brook granodiorite, Kathy Road diorite, Baddeck River granodiorite, Shunacadie granite, and Boisdale Hills tonalite dyke) are shown for comparison. Data sources are referenced in the text. 

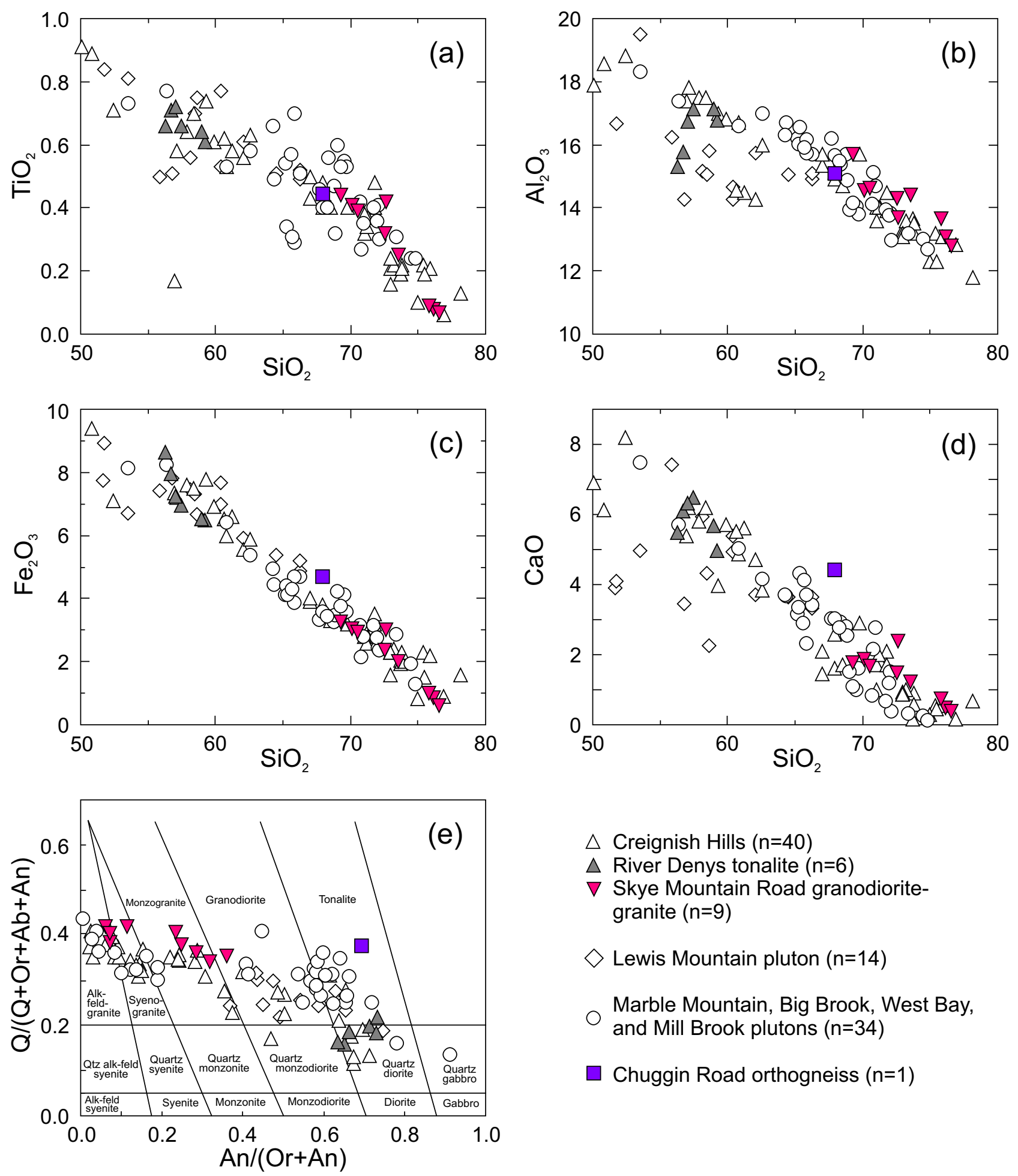

$\triangle$ Creignish Hills $(n=40)$

$\triangle$ River Denys tonalite $(n=6)$

$\nabla$ Skye Mountain Road granodioritegranite $(n=9)$

Lewis Mountain pluton $(n=14)$

Marble Mountain, Big Brook, West Bay, and Mill Brook plutons $(n=34)$

Chuggin Road orthogneiss $(n=1)$

Figure 7. Plots of (a) $\mathrm{TiO}_{2}$, (b) $\mathrm{Al}_{2} \mathrm{O}_{3}$, (c) $\mathrm{Fe}_{2} \mathrm{O}_{3}{ }^{\mathrm{T}}$, and (d) $\mathrm{CaO}$ against $\mathrm{SiO}_{2}$ and (e) normative mineralogy to illustrate chemical variation in the ca. 560-550 Ma plutonic rocks of the Creignish Hills - North Mountain areas. Data are from Table D1 and sources cited in Table D2. Fields in (e) are from Streckeisen and LeMaitre (1979). 

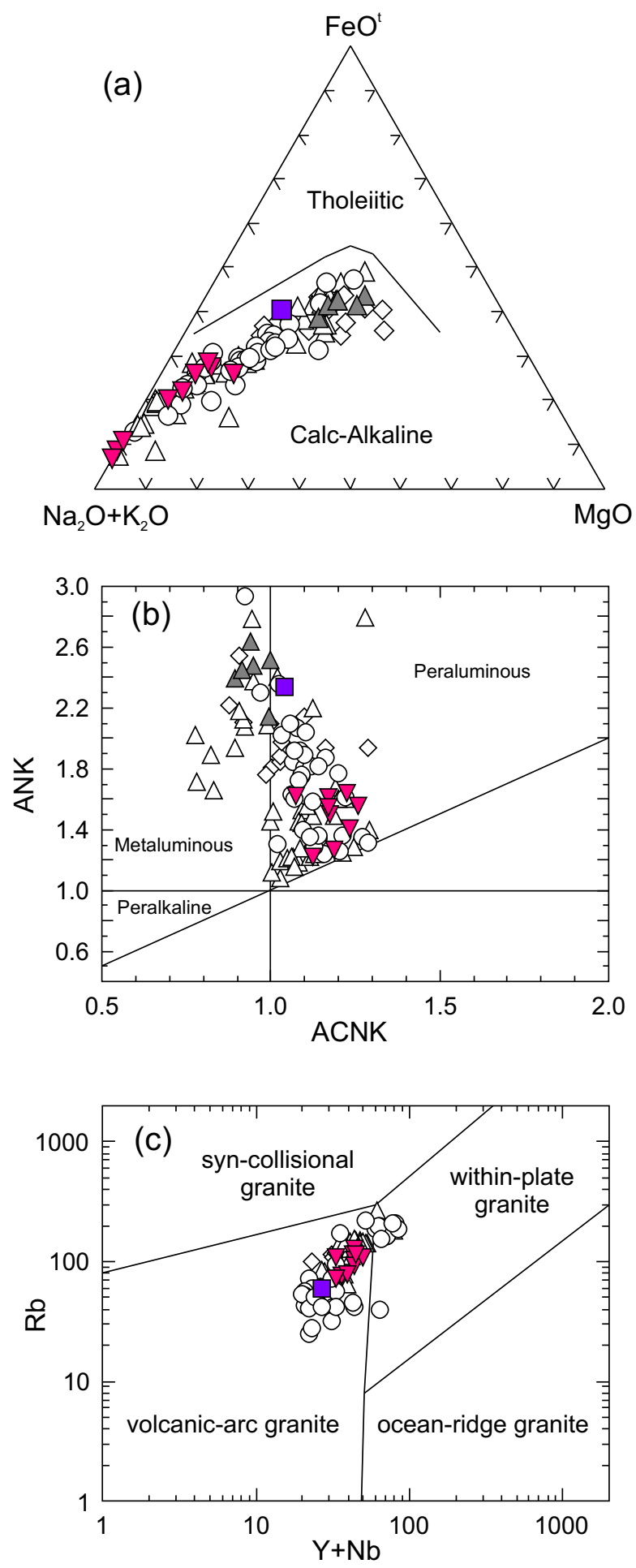

Figure 8. Diagrams to illustrate chemical affinity and tectonic setting for ca. 560-550 Ma plutonic rocks of the Creignish Hills - North Mountain areas. (a) AFM diagram with tholeiitic-calc-alkalic dividing line after Irvine and Baragar (1971). (b) Plot of molecular proportions of $\mathrm{Al}_{2} \mathrm{O}_{3} /\left(\mathrm{Na}_{2} \mathrm{O}+\mathrm{K}_{2} \mathrm{O}\right)$ against $\mathrm{Al}_{2} \mathrm{O}_{3} /\left(\mathrm{CaO}+\mathrm{Na}_{2} \mathrm{O}+\mathrm{K}_{2} \mathrm{O}\right)$. (c) Tectonic setting discrimination diagram with fields from Pearce et al. (1984). Symbols are as in Figure 7.
Brook Formation (Fig. 2). The age data shown in Figure 5 are statistically too few to attach significance to the internal peaks, but if the upper and lower bounds of the data have significance, they suggest that muscovite with a minimum age of $500 \mathrm{Ma}$ was variably reset at about $430 \mathrm{Ma}$. The other age data (U-Pb zircon and monazite and ${ }^{40} \mathrm{Ar} /{ }^{39} \mathrm{Ar}$ amphibole) suggest that the likely initial age of the muscovite is ca. 550 $\mathrm{Ma}$, the approximate time of regional metamorphism and pluton emplacement in the Bras d'Or terrane. Scattered plutons elsewhere in the Bras d'Or terrane with ages of ca. 500 $\mathrm{Ma}$ are post-tectonic, and little other evidence exists for a ca. $500 \mathrm{Ma}$ thermal event in the Bras d'Or terrane (Figs. 6a, b). The variable resetting of the muscovite ages could have been related to the emplacement of the Skye Mountain dioritegabbro at ca. $438 \mathrm{Ma}$, but given that the young muscovite ages occur widely through the Creignish Hills (Dallmeyer and Keppie 1993), it seems more likely that the resetting was related to deformation in the major shear zones in the area (Fig. 2). More detailed ${ }^{40} \mathrm{Ar} /{ }^{39} \mathrm{Ar}$ work throughout the Bras d'Or terrane is needed in order to interpret the Paleozoic thermal history as recorded in these muscovite ages.

\section{CONCLUSIONS}

The U-Pb ages presented here for detrital zircon in the Blues Brook Formation of the Creignish Hills confirm the hints of Late Neoproterozoic ages reported by Keppie et al. (1998a) and show without doubt that the depositional age of the unit is no greater than about $600 \mathrm{Ma}$. Although it is possible that some components of the formation are much older, such as the quartzite in which the youngest detrital zircon age obtained is ca. $1000 \mathrm{Ma}$ (Keppie et al. 1998a), similarities in rock types and contiguous field relations suggest that this is not the case. Based on similarities in rock types and previously published detrital zircon ages of ca. $690 \mathrm{Ma}$ (Keppie et al. 1998a), it is likely that the highgrade metasedimentary rocks of the Melford Formation and Chuggin Road complex are of the same age, and that they represent the same or stratigraphically equivalent units at higher metamorphic grade, rather than unrelated units. The minimum ages of both the low- and high-grade units in the Creignish Hills and nearby North Mountain are provided by cross-cutting syn- and post-tectonic plutons with ages of mainly 565-550 Ma, indicating that sediments were deposited, regionally metamorphosed and deformed, and intruded by plutons in less than 40-50 million years. The assemblage of pelitic, psammitic, and carbonate rocks indicates that a passive margin in a tropical climate was quickly changed to an active Andean-type continental margin in which voluminous calc-alkaline dioritic to granitic plutons were emplaced. This sedimentary and tectonic history is characteristic of the Bras d'Or terrane and is shared by its likely correlative, the Brookville terrane in southern New Brunswick (Barr et al. 2014b). 


\section{ACKNOWLEDGEMENTS}

This paper assembles information gathered over many years and we are grateful to those who contributed information as cited in the paper, but especially Janet Campbell whose MSc thesis laid the groundwork for much of the subsequent work, and also her supervisor Rob Raeside. Funding was provided by Geological Survey of Canada's Targeted Geoscience Initiative 1 (TGI-1) and the Nova Scotia Department of Natural Resources. Sandra Barr's work on this project was funded mainly by grants over many years from the Natural Sciences and Engineering Research Council of Canada. Special thanks to Tracy Lenfesty and Janelle Brenton for providing help in the departmental library and Trevor MacHattie is thanked for comments on an earlier draft of the manuscript. We thank the journal reviewers Rob Raeside and Deanne van Rooyen for their helpful comments and suggestions which improved the manuscript. This paper is published with permission of the Director, Nova Scotia Department of Natural Resources.

\section{REFERENCES}

Armitage, A.E. 1989. Geology and petrology of the crystalline rocks of the Whycocomagh area, Cape Breton Island, Nova Scotia. Unpublished B.Sc.H. thesis. Acadia University, Wolfville, Nova Scotia, $120 \mathrm{p}$.

Barr, S.M. and Jamieson, R.A. 1991. Tectonic setting and regional correlations of Ordovician-Silurian metavolcanic rocks of the Aspy Terrane, Cape Breton Island, Nova Scotia. Canadian Journal of Earth Sciences, 28, pp. 17691779. http://dx.doi.org/10.1139/e91-158

Barr, S.M. and Raeside, R.P. 1989. Tectono-straigraphic terranes in Cape Breton Island, Nova Scotia: Implications for the configuration of the northern Appalachian orogen. Geology, 17,pp. 822-825. http://dx.doi.org/10.1130/00917613(1989)017<0822:TSTICB >2.3.CO;2

Barr, S.M., Raeside, R.P., Miller, B.V., and White, C.E. 1995. Terrane evolution and accretion in Cape Breton Island, Nova Scotia. In New perspectives in the Appalachian orogen. Edited by J. Hibbard, P. Cawood, S. ColmanSadd, and C. van Staal. Geological Association of Canada Special Paper 41, pp. 391-407.

Barr, S.M., White, C.E., and Macdonald, A.S. 1996. Stratigraphy, tectonic setting, and geological history of Late Precambrian volcanic-sedimentary-plutonic belts in southeastern Cape Breton Island, Nova Scotia. Geological Survey of Canada, Bulletin 468, 84p. http://dx.doi. org/10.4095/208235

Barr, S.M., Raeside, R.P., and White, C.E. 1998. Geological correlations between Cape Breton Island and Newfoundland, northern Appalachian orogen. Canadian Journal of Earth Sciences, 35, 1252-1270. http://dx.doi. org/10.1139/e98-016
Barr, S.M., Davis, D.W., Kamo, S., and White, C.E. 2003. Significance of $\mathrm{U}-\mathrm{Pb}$ ages of detrital zircon in quartzite from peri-Gondwanan terranes, New Brunswick and Nova Scotia, Canada. Precambrian Research, 126, pp. 123-145. http://dx.doi.org/10.1016/S0301-9268(03)00192-X

Barr, S.M., White, C.E., and Ketchum, J.W.F. 2012. The Cape Porcupine Complex, northern mainland Nova Scotia no longer a geological orphan. Atlantic Geology, 48, pp. 70-85. http://dx.doi.org/10.4138/atlgeol.2012.004

Barr, S.M., Pin, C., McMullin, D.W.A., and White, C.E. 2013. Whole-rock chemical and $\mathrm{Nd}$ isotopic composition of a Late Proterozoic metasedimentary sequence in Ganderia: Kellys Mountain, Bras d'Or terrane, Nova Scotia, Canada. Atlantic Geology, 49, pp. 57-69. http:// dx.doi.org/10.4138/atlgeol.2013.002

Barr, S.M., Dehler, S.A., and Zsámboki, L. 2014a. Connecting Cape Breton Island and Newfoundland, Canada: Geophysical modeling of pre-Carboniferous "basement" rocks in the Cabot Strait area. Geoscience Canada, 41, pp. 186-206. http://dx.doi.org/10.12789/geocanj.2014.41.041

Barr, S.M., White, C.E., Davis, D.W., McClelland, W.C., and van Staal, C.R. 2014b. Infrastructure and provenance of Ganderia: evidence from detrital zircon ages in the Brookville terrane, southern New Brunswick, Canada. Precambrian Research, 246, pp. 358-370. http://dx.doi. org/10.1016/j.precamres.2014.03.022

Campbell, J.E.M. 1990. The geology of the northeastern Creignish Hills, Cape Breton Island, Nova Scotia. Unpublished M.Sc. thesis, Acadia University, Wolfville, Nova Scotia, Canada, 164 p.

Dallmeyer, R.D. and Keppie, J.D. $1993 .{ }^{40} \mathrm{Ar} /{ }^{39} \mathrm{Ar}$ mineral ages from the southern Cape Breton Highlands and Creignish Hills, Cape Breton Island, Canada: evidence for a polyphase tectonothermal evolution. Journal of Geology, 101, pp. 467-482. http://dx.doi.org/10.1086/648240

Davis, D.W. 1982. Optimum linear regression and error estimation applied to $\mathrm{U}-\mathrm{Pb}$ data. Canadian Journal of Earth Sciences, 19, pp. 2141-2149. http://dx.doi. org/10.1139/e82-188

Farrow, C.E.G. and Barr, S.M. 1992. Petrology of highalumina hornblende and magmatic epidote-bearing plutons, southeastern Cape Breton Highlands, Nova Scotia. Canadian Mineralogist, 30, pp. 377-392.

Giles, P.S., Naylor, R.D., Teniere, P.J., White, C.E., Barr. S.M., and DeMont, G.J. 2010. Geology of Port Hawkesbury (NTS 11F/11, 11F/06, 11F/07, 11F/10). Nova Scotia Department of Natural Resources, Minerals and Energy Branch, Open File Map, scale 1:50 000.

Grecco, L. and Barr, S.M. 1999. Late Neoproterozoic granitoid and metavolcanic rocks of the Indian Brook area, southeastern Cape Breton Highlands, Nova Scotia. Atlantic Geology, 35, pp. 43-57. http://dx.doi. org/10.4138/2023

Hames, W.E., Cheney, J.T., and Tracy, R.J. 2008. Single-crystal ${ }^{40} \mathrm{Ar} /{ }^{39} \mathrm{Ar}$ age variation in muscovite of the Gassetts Schist 
and associated gneiss, Vermont Appalachians. American Mineralogist, 93, pp. 384-395. http://dx.doi.org/10.2138/ am.2008.2641

Hibbard, J.P., van Staal, C.R., Rankin, D.W., and Williams, H. 2006. Lithotectonic map of the Appalachian orogen, Canada - United States of America: Geological Survey of Canada Map 02096A, 2 sheets, scale 1:1 500000.

Hofmann, H. J. 1974. The stromatolite Archaeozoon acadiense from the Proterozoic Greenhead Group of Saint John, New Brunswick. Canadian Journal of Earth Sciences, 11, pp. 1098-1115. http://dx.doi.org/10.1139/ e74-105

Horton, D.A. 1994. The geology and petrology of the Skye Mountain pluton, Cape Breton Island, Nova Scotia. Unpublished B.Sc.H. thesis, Saint Mary's University, Halifax, Nova Scotia, 103 p.

Irvine, T.N. and Baragar, W.R. A. 1971. A guide to the chemical classification of the common volcanic rocks. Canadian Journal of Earth Sciences, 8, pp. 523-548. http://dx.doi.org/10.1139/e71-055

Jaffey, A.H., Flynn, K.F., Glendenin, L.E., Bentley, W.C., and Essling, A.M. 1971. Precision measurement of half-lives and specific activities of ${ }^{235} \mathrm{U}$ and ${ }^{238} \mathrm{U}$. Physical Review, 4, pp. 1889-1906.

Justino, M. 1991. Geology and petrogenesis of granitoid rocks in the North Mountain area, southwestern Cape Breton Island, Nova Scotia. Unpublished M.Sc. thesis, Acadia University, Wolfville, Nova Scotia, 327 p.

Justino, M. and Barr, S.M. 1994. Petrology, petrogenesis, and tectonic setting of plutonic rocks in the North Mountain area, west-central Cape Breton Island, Nova Scotia. Atlantic Geology, 30, pp. 47-64. http://dx.doi. org/10.4138/2119

Kelley, D.G. 1967. Baddeck and Whycocomagh map areas - with emphasis on Mississippian stratigraphy of Cape Breton Island. Geological Survey of Canada, Memoir 351. $65 \mathrm{p}$.

Keppie, J.D. 1979. Geological map of the Province of Nova Scotia. Nova Scotia Department of Mines and Energy, scale 1:500 000.

Keppie, J.D. 1993. Geology of the eastern Creignish Hills, central Cape Breton Island: implications for gold mineralization. Nova Scotia Department of Natural Resources, Mines and Energy Branch, Report 93-2, p. 26.

Keppie, J.D. (Compiler). 2000. Geological map of the province of Nova Scotia. Nova Scotia Department of Natural Resources and Energy, Map ME2000-1, scale 1:500 000 .

Keppie, J.D. and Dostal, J. 1998. Birth of the Avalon arc in Nova Scotia, Canada: geochemical evidence for $\sim 700$ 630 Ma back-arc rift volcanism off Gondwana. Geological Magazine, 135, pp. 171-181. http://dx.doi.org/10.1017/ S0016756898008322

Keppie, J.D., Dallmeyer, R.D., and Murphy, J.B. 1990. Tectonic implications of ${ }^{40} \mathrm{Ar} /{ }^{39} \mathrm{Ar}$ hornblende ages from late Proterozoic-Cambrian plutons in the Avalon Composite Terrane, Nova Scotia, Canada. Geological Society of America Bulletin, 102, pp. 516-528. http:// dx.doi.org/10.1130/0016-7606(1990)102<0516:TIOAAH $>2.3 . \mathrm{CO} ; 2$

Keppie, J.D., Davis, D.W., and Krogh, T.E. 1998a. U-Pb geochronological constraints on Precambrian stratified units in the Avalon Composite Terrane of Nova Scotia, Canada: tectonic implications. Canadian Journal of Earth Sciences, 35, pp. 222-236. http://dx.doi.org/10.1139/e97109

Keppie, J.D., Dostal, J., Davis, D.W., and Horton, D.A. 1998 b. Earliest Silurian supra-subduction magmatism in central Cape Breton Island. Atlantic Geology, 34, pp. 113-120. http://dx.doi.org/10.4138/2042

Keppie, J.D., Dostal, J., Dallmeyer, R.D., and Doig, R. 2000. Superposed Neoproterozoic and Silurian magmatic arcs in central Cape Breton Island, Canada: geochemical and geochronological constraints. Geological Magazine, 137, pp. 137-153. http://dx.doi.org/10.1017/ S0016756800003769

King, M.S. 2002. The Mira-Bras d'Or terrane boundary in Cape Breton Island, Nova Scotia: potential field and petrophysical investigations applied to tectonic analysis in the northern Appalachian orogen. Unpublished M.Sc. thesis, Acadia University, Wolfville, Nova Scotia, 195 p.

Krogh, T.E. 1973. A low contamination method for hydrothermal decomposition of zircon and extraction of $\mathrm{U}$ and $\mathrm{Pb}$ for isotopic age determinations. Geochimica et Cosmochimica Acta, 37, pp. 485-494. http://dx.doi. org/10.1016/0016-7037(73)90213-5

Krogh, T.E. 1982. Improved accuracy of U-Pb ages by the creation of more concordant systems using an air abrasion technique. Geochimica et Cosmochimica Acta, 46, pp. 637-649. http://dx.doi.org/10.1016/00167037(82)90165-X

Kuiper, K.F., Deino, A., Hilgen, F.J., Krijgsman, W., Renne, P.R., and Wijbrans, J.R. 2008. Synchronizing rock clocks of earth history. Science, 320, pp. 500-504. http://dx.doi. org/10.1126/science.1154339

Lin, S. 1993. Relationship between the Aspy and Bras d'Or "terranes" in the northeastern Cape Breton Highlands, Nova Scotia. Canadian Journal of Earth Sciences, 30, pp. 1773-1781. http://dx.doi.org/10.1139/e93-157

Lin, S. 1995. Structural evolution and tectonic significance of the Eastern Highlands shear zone in Cape Breton Island, the Canadian Appalachians. Canadian Journal of Earth Sciences, 32, pp. 545-554. http://dx.doi.org/10.1139/e95046

Lin, S. 2001. ${ }^{40} \mathrm{Ar} /{ }^{39} \mathrm{Ar}$ age pattern associated with differential uplift along the Eastern Highlands shear zone, Cape Breton Island, Canadian Appalachians. Journal of Structural Geology, 23, pp. 1031-1042. http://dx.doi. org/10.1016/S0191-8141(00)00174-7

Lin, S., Davis, D.W., Barr, S.M., van Staal, C.R., Chen, Y., and 
Constantin, M. 2007. U-Pb geochronological constraints on the evolution of the Aspy Terrane, Cape Breton Island: Implications for relationships between Aspy and Bras d'Or terranes and Ganderia in the Canadian Appalachians. American Journal of Science, 307, pp. 371-398. http:// dx.doi.org/10.2475/02.2007.03

Ludwig, K.R. 2003. User's manual for Isoplot 3.00 a geochronological toolkit for Excel. Berkeley Geochronological Center Special Publication 4, 71 p.

Lynch, G. and Brisson, H. 1996. Bedrock geology, Whycocomagh $(11 \mathrm{~F} / 14)$. Geological Survey of Canada, Open File 2917, scale 1:50 000.

Milligan, G.C. 1970. Geology of the George River Series, stratigraphy, structure, and economic geology. Province of Nova Scotia, Department of Mines, Memoir 7. 111 p.

Mulch, A. and Cosca, M.A. 2004. Crystallization or cooling ages? In situ UV-laser ${ }^{40} \mathrm{Ar} /{ }^{39} \mathrm{Ar}$ geochronology of muscovite in mylonitic rocks. Journal of the Geological Society London, 161, pp. 573-582. http://dx.doi. org/10.1144/0016-764903-110

Pearce, J.A., Harris, N. W. B., and Tindle, A. G. 1984. Trace element discrimination diagrams for the tectonic interpretation of granitic rocks. Journal of Petrology, 25, pp. 956-983. http://dx.doi.org/10.1093/petrology/25.4.956

Potter, J., Longstaffe, F.J., Barr, S.M., Thompson, M.D., and White, C.E. 2008a. Altering Avalonia: oxygen isotopes and terrane distinction. Canadian Journal of Earth Sciences, 45, pp. 815-825.

Potter, J., Longstaffe, F.J., and Barr, S.M. 2008b. Regional ${ }^{18} \mathrm{O}$-depletion in Neoproterozoic igneous rocks of Avalonia, Cape Breton Island \& southern New Brunswick, Canada. Geological Society of America Bulletin, 120, pp. 347-367. http://dx.doi.org/10.1130/B26191.1

Price, J., Barr, S.M., Raeside, R.P., and Reynolds, P. 1999. Petrology, tectonic setting, and ${ }^{40} \mathrm{Ar} /{ }^{39} \mathrm{Ar}$ (hornblende) dating of the Late Ordovician-Early Silurian Belle Cote Road orthogneiss, western Cape Breton Highlands, Nova Scotia. Atlantic Geology, 35, pp. 1-17. http://dx.doi. org/10.4138/2021

Raeside, R.P. 1990. Low-pressure metamorphism of the Lime Hill gneissic complex, Bras d'Or Terrane, Cape Breton Island, Nova Scotia. In Mineral deposits of Nova Scotia. Edited by A. L. Sangster. Geological Survey of Canada, Paper 90-8, pp. 67-76.

Raeside, R.P. and Barr, S.M. 1990. Geology and tectonic development of the Bras d'Or suspect terrane, Cape Breton Island, Nova Scotia. Canadian Journal of Earth Sciences, 27, pp. 1317-1381. http://dx.doi.org/10.1139/ e90-147

Renne, P.R., Swisher, C.C., Deino, A.L., Karner, D.B., Owens, T.L., and DePaolo, D.J. 1998. Intercalibration of standards, absolute ages and uncertainties in ${ }^{40} \mathrm{Ar} /{ }^{39} \mathrm{Ar}$ dating. Chemical Geology, 145, pp. 117-152. http:// dx.doi.org/10.1016/S0009-2541(97)00159-9
Rogers, N., van Staal, C. R., McNicoll, J., Pollock, J., Zagorevski, A., and Whalen, J. 2006. Neoproterozoic and Cambrian arc magmatism along the eastern margin of the Victoria Lake Supergroup: A remnant of Ganderian basement in central Newfoundland. Precambrian Research 147, pp. 329-341. http://dx.doi.org/10.1016/j. precamres.2006.01.025

Sangster, A.L., Hunt, P.A., and Mortensen, J.K. 1990. U-Pb geochronology of the Lime Hill gneissic complex, Cape Breton Island, Nova Scotia. Atlantic Geology, 26, pp. 229236. http://dx.doi.org/10.1007/s00410-006-0077-4

Schoene, B. and Bowring, S.A. 2006. U-Pb systematics of the McClure Mountain syenite: thermochronological constraints on the age of the ${ }^{40} \mathrm{Ar} /{ }^{39} \mathrm{Ar}$ standard MMhb. Contributions to Mineralogy and Petrology, 151, pp. 615630. http://dx.doi.org/10.1007/s00410-006-0077-4

Streckeisen, A. and Le Maitre, R.W. 1979. A chemical approximation to the modal QAPF classification of the igneous rocks. Neues Jahrbuch für Mineralogie, 136, pp. 169-206.

Swanton, D. 2010. Field relations, petrology, tectonic setting and economic potential of metamorphic and igneous rocks in the Whycocomagh Mountain -Aberdeen Ridge area, Cape Breton Island, Nova Scotia. Unpublished M.Sc. thesis, Acadia University, Wolfville, Nova Scotia, 204 p.

Swanton, D.A., White, C.E., and Barr, S.M. 2010. Bedrock geology in the Whycocomagh Mountain-Aberdeen Ridge area, central Cape Breton Island, Nova Scotia In Mineral Resources Branch, Report of Activities 2009. Edited by D.R. MacDonald. Nova Scotia Department of Natural Resources, Report ME 2010-1, pp. 113-123.

Tomlinson, K.Y., Davis, D.W., Stone, D., and Hart, T.R. 2003. U-Pb age and $\mathrm{Nd}$ isotopic evidence for crustal recycling and Archean terrane development in the southcentral Wabigoon subprovince, Canada. Contributions to Mineralogy and Petrology, 144, pp. 684-702. http:// dx.doi.org/10.1007/s00410-002-0423-0

Wasylik, D., White, C.E., and Barr, S.M. 2005. Geology of the Washabuck Peninsula, central Cape Breton Island, Nova Scotia. In Mineral Resources Branch, Report of Activities 2004, Edited by D.R. MacDonald. Nova Scotia Department of Natural Resources, Report ME 2005-1, pp. $117-128$.

Wessel, Z.R., Nance, R.D., Keppie, J.D., and Murphy, J.B. 2005. Structural analysis of the Creignish Hills mylonite zone, Cape Breton Island, Nova Scotia; implications for Neoproterozoic core complex development along the northern Gondwanan margin? Journal of Geodynamics, 39, pp. 231-246. http://dx.doi.org/10.1016/j.jog.2004.11. 002

White, C.E. and Barr, S.M. 1996. Geology of the Brookville terrane, southern New Brunswick, Canada. In Avalonian and related peri-Gondwanan terranes of the CircumNorth Atlantic. Edited by R.D. Nance and M.D. Thompson. 
Geological Society of America, Special Paper 304, pp. 133-147. http://dx.doi.org/10.1130/0-8137-2304-3.133

White, C.E. and Boehner, R.C. 2008. Bedrock geology map of the Whycocomagh area (NTS 11F/14), Inverness County, Nova Scotia. Nova Scotia Department of Natural Resources, Mineral Resources Branch, Open File Map ME2008-1, scale 1:50 000.

White, C.E., Barr, S.M., and Campbell, R.M. 1990. Petrology of the Creignish Hills Pluton, Cape Breton Island, Nova Scotia. Atlantic Geology, 26, pp. 109-123. http://dx.doi. org/10.4138/1696

White, C.E., Barr, S.M., Miller, B.V., and Hamilton, M.A. 2002. Granitoid plutons of the Brookville terrane, southern New Brunswick: Petrology, age, and tectonic setting. Atlantic Geology, 38, pp. 53-74.

White, C.E., Barr, S.M., and Ketchum, J.W.F. 2003. New age controls on rock units in pre-Carboniferous basement blocks in southwestern Cape Breton Island and adjacent mainland Nova Scotia. In Nova Scotia Department of Natural Resources, Minerals and Energy Branch, Report of Activities 2002. Edited by D.R. MacDonald. Report ME 2003-1, pp. 163-178.

White, C.E., Boehner, R.C., and DeMont, G.J. 2007. Geology of the Whycocomagh map area $(11 \mathrm{~F} / 14)$, Inverness County, Nova Scotia. In Mining Matters 2007 and Industry Investment Forum. Edited by K.A. Mills and D.R. MacDonald. Nova Scotia Department of Natural Resources, Mineral Resources Branch, Report ME 20072, p.14.

Editorial responsibility: David P. West, Jr.

\section{APPENDIX A}

Schist sample SMB14-189A was processed and analyzed in the Jack Satterly Geochronology Laboratory at the University of Toronto. It was crushed using a jaw crusher followed by a disk mill. Initial separation of heavy minerals was carried out with a Wilfley table, followed by paramagnetic separations with the Frantz isodynamic separator and density separations using bromoform and methylene iodide. Final sample selection for geochronology was by hand picking under a microscope, choosing the freshest, least cracked zircon grains. Laser ablation inductively coupled plasma mass spectrometry (LA-ICPMS) was used to obtain age data using a VG Series 2 Plasmaquad ICPMS and $213 \mathrm{~nm}$ New Wave laser system. Sensitivity was enhanced by the use of a $75 \mathrm{l} / \mathrm{sec}$ rotary pump (S-option) connected to the expansion chamber. Whole sample grains were mounted on double-sided tape for LA-ICPMS analysis. This has the advantage that interesting samples (e.g., the youngest grains from a detrital population) can be easily removed and re-dated by ID-TIMS and the amount of material available for analysis is maximized for small grains. The disadvantage is that cores and overgrowths or cracks and altered domains cannot be easily distinguished.

Grains were partially ablated using a $213 \mathrm{~nm}$ laser beam with diameters of $18-25$ microns at $5 \mathrm{~Hz}$ and $40 \%$ power. For zircon, data were collected on ${ }^{88} \mathrm{Sr}(10 \mathrm{~ms}),{ }^{206} \mathrm{~Pb}(30 \mathrm{~ms})$, ${ }^{207} \mathrm{~Pb}(90 \mathrm{~ms}),{ }^{232} \mathrm{Th}(10 \mathrm{~ms})$ and ${ }^{238} \mathrm{U}(20 \mathrm{~ms})$. Sr is a proxy for alteration or the presence of inclusions. Data with excessive Sr signals were rejected. Immediately prior to each analysis, the spot was pre-ablated over a larger area than the beam diameter for about $10 \mathrm{sec}$ to clean the surface and remove any surface alteration. Following a $10 \mathrm{sec}$ period of baseline accumulation the laser sampling beam was turned on and data were collected for 25 seconds. Rasters and sampling were separated by a $50 \mathrm{sec}$ washout period. About 150 measurement cycles per sample were produced and ablation pits are about 15 microns deep. In some cases data profiles show rapidly varying emission due to chemical zoning of zircon. Instability was dampened through the use of a $25 \mathrm{ml}$ mixing chamber in-line with the $\mathrm{He}$ flow transporting the ablated sample to the plasma. Data were edited and reduced using custom VBA software (UTILLAZ program) written by the D. Davis. ${ }^{206} \mathrm{~Pb} /{ }^{238} \mathrm{U}$ show only slight fractionation caused by hole depth through the run and most of the ${ }^{207} \mathrm{~Pb} /{ }^{206} \mathrm{~Pb}$ and ${ }^{206} \mathrm{~Pb} /{ }^{238} \mathrm{U}$ data can be averaged. No corrections were made for common $\mathrm{Pb}$ since the ${ }^{204} \mathrm{~Pb}$ peak is too small for useful measurement and common $\mathrm{Pb}$ should be negligible in fresh zircon and monazite. The Th/U ratio of zircon can be a useful petrogenetic indicator and was also measured, although it is only a rough estimate because the ratio is not constant in the standard. Low $\mathrm{Th} / \mathrm{U}(<0.1)$ is characteristic of metamorphic zircon. Igneous zircon usually shows $\mathrm{Th} / \mathrm{U}$ the range 0.1-1.0. Zircon from sample DD8-17, a quartz diorite from the northwest Ontario dated at $3002 \pm 2 \mathrm{Ma}$ (Tomlinson et al. 2003) was used as a standard. Sets of 3 sample measurements are bracketed by measurements on standards.

For Precambrian samples, ${ }^{207} \mathrm{~Pb} /{ }^{206} \mathrm{~Pb}$ ages are more accurate and precise than ${ }^{207} \mathrm{~Pb} /{ }^{235} \mathrm{U}$ or ${ }^{206} \mathrm{~Pb} /{ }^{238} \mathrm{U}$ ages. Numerical results of U-Pb isotopic analyses by LA-ICPMS are given in Table A1. Errors are at one sigma. These reflect reproducibility of individual data profiles. They do not include error from sample-standard reproducibility, which may be several percent for $\mathrm{Pb} / \mathrm{U}$ but is unlikely to exceed 1 percent for ${ }^{207} \mathrm{~Pb} /{ }^{206} \mathrm{~Pb}$. Concordia data are plotted using the Isoplot program of Ludwig (2003). Error ellipses and regression errors are given at $95 \%$ confidence levels. U decay constants are from Jaffey et al. (1971).

\section{APPENDIX B}

Samples SMB02-79, SMB02-81, and SMB02-83 were processed at the ROM using a jaw crusher for initial crushing, a disk mill for sample reduction to sand-sized 
Table A1. LA-ICPMS analyses on zircon from Creignish Hills metasedimentary sample SMB14-189A.

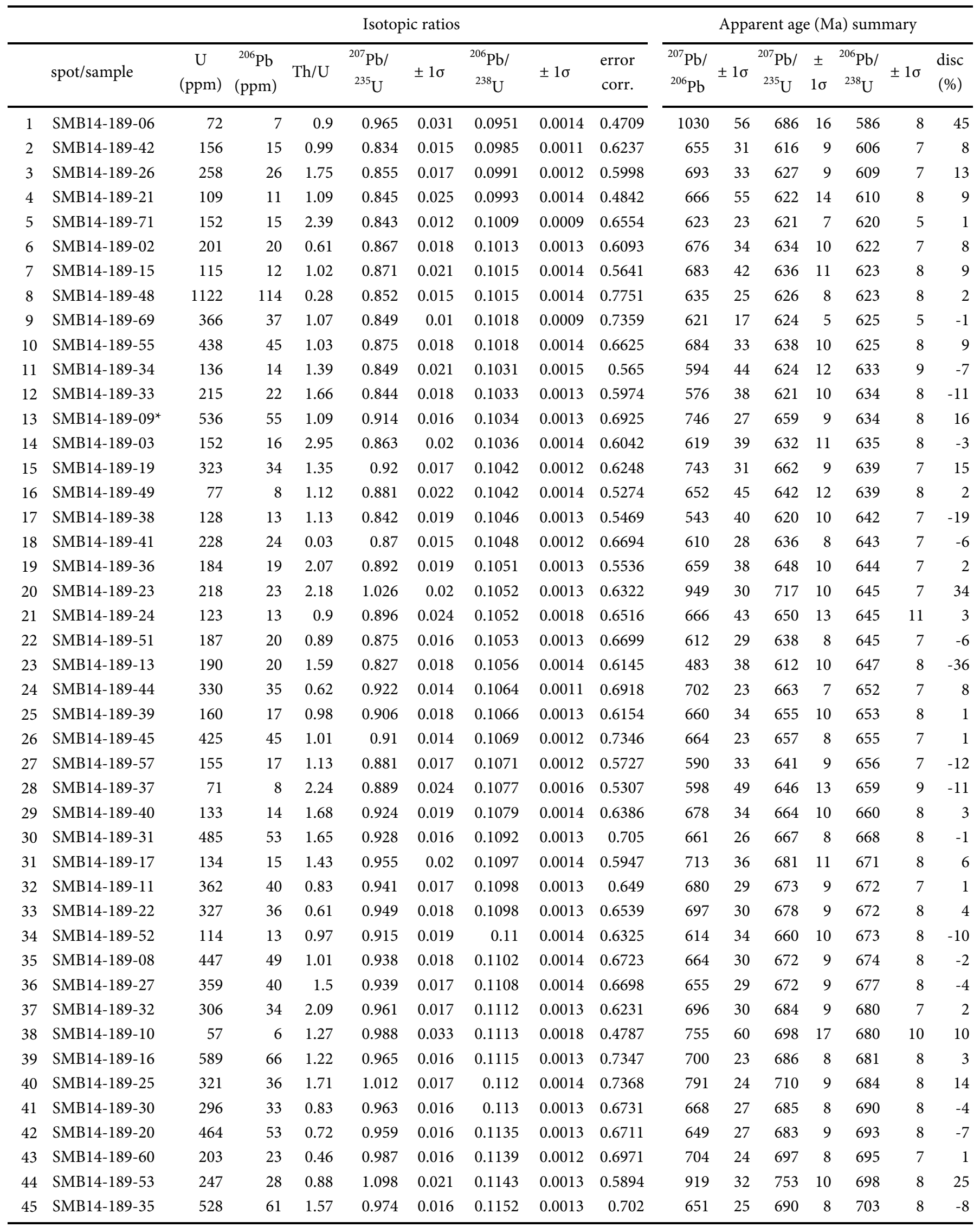


Table A1. Continued.

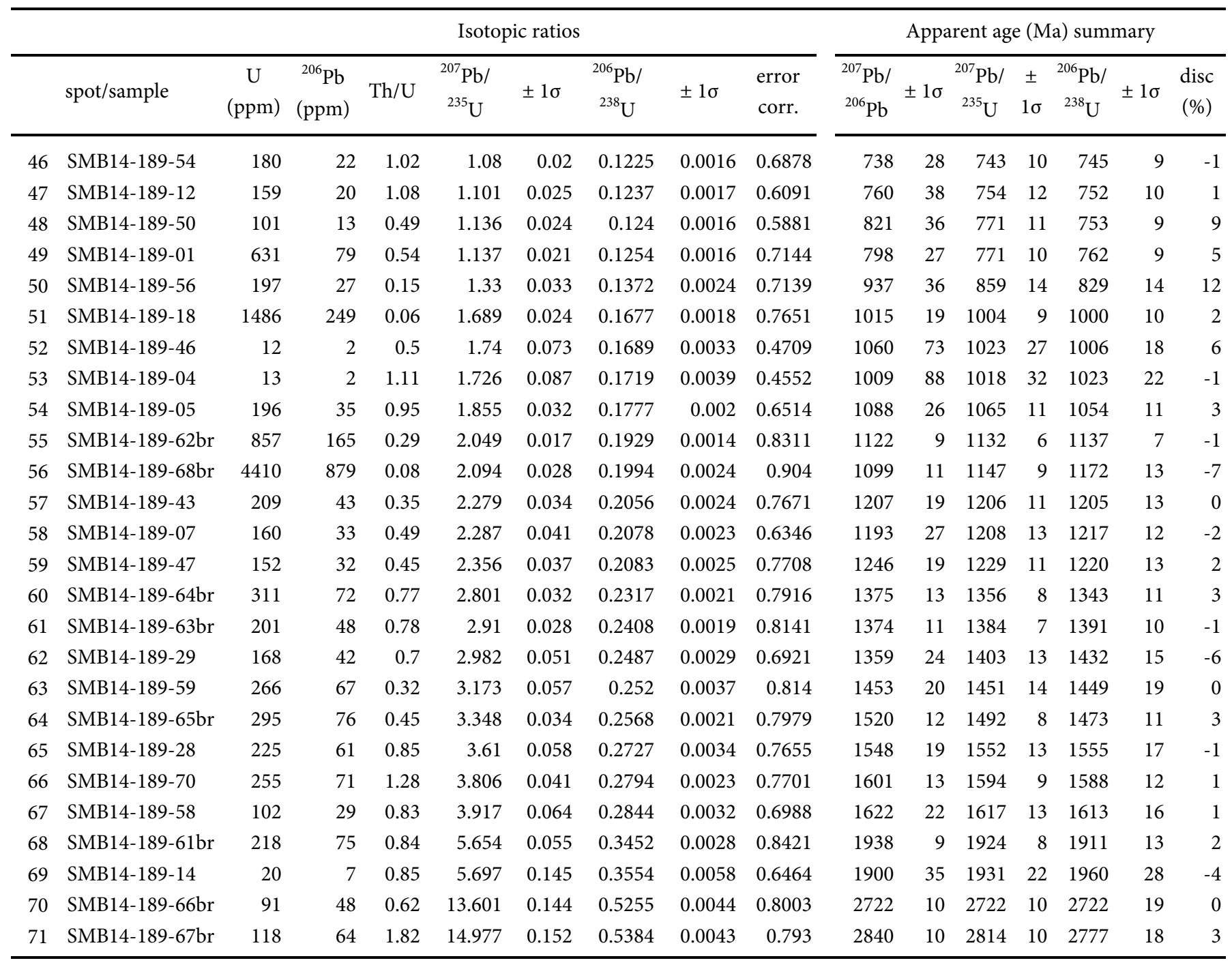

Notes: ${ }^{\star}$ High Sr; analyses are arranged from lowest to highest ${ }^{206} \mathrm{~Pb} /{ }^{238} \mathrm{U}$ age; br $=$ brownish; error correl. = Error correlation coefficient for concordia coordinates; disc $(\%)=$ discordance; relation between ages and concordia coordinates: $\mathrm{Y}={ }^{206} \mathrm{~Pb} /{ }^{238} \mathrm{U}=\mathrm{EXP}\left(\mathrm{L} 238^{\star}\left({ }^{206-238} \mathrm{Age}\right)\right)$ $1 ; \mathrm{X}={ }^{207} \mathrm{~Pb} /{ }^{235} \mathrm{U}=\mathrm{EXP}\left(\mathrm{L} 235^{\star}\left({ }^{207-235} \mathrm{Age}\right)\right)-1 .{ }^{207} \mathrm{~Pb} /{ }^{206} \mathrm{~Pb}=137.88^{\star} \mathrm{X} / \mathrm{Y} ; \mathrm{U}$ decay constants (L238 \& L235) from Jaffey et al . (1971).

particles, and a Wilfley table, heavy liquids (bromoform and methylene iodide) and a Frantz magnetic separator for isolation of heavy mineral fractions. Zircon was selected from the least paramagnetic fraction by hand picking under a binocular microscope. All picked zircons were given an air abrasion treatment to eliminate cracked grains and remove exterior surfaces (Krogh 1982). Final selection of grains for analysis was then made. The weight of each fraction (typically one or two grains) was either estimated or measured using a microbalance. As the weights are normally small (generally $<3$ micrograms), both the measured and estimated weights are accurate only to about $\pm 50 \%$. However, this only affects the calculation of
$\mathrm{Pb}$ and $\mathrm{U}$ concentrations and has no influence on age data.

The selected grains were washed in $4 \mathrm{~N}$ and then $7 \mathrm{~N}$ $\mathrm{HNO}_{3}$ and then loaded into Teflon bombs with $\mathrm{HF}$ and a measured amount of ${ }^{205} \mathrm{~Pb}-{ }^{235} \mathrm{U}$ isotopic tracer solution (Krogh 1973). Dissolution occurred over four to five days at $195^{\circ} \mathrm{C}$. No chemical isolation of $\mathrm{U}$ and $\mathrm{Pb}$ was carried out on the dissolved grains. Fractions were dried down with phosphoric acid and then loaded with silica gel onto outgassed rhenium filaments. The isotopic compositions of $\mathrm{Pb}$ and $\mathrm{U}$ were measured using a single Daly collector with a pulse counting detector in a solid source VG354 mass spectrometer. A detector mass discrimination of $0.14 \%$ per atomic mass unit (AMU) and a deadtime of 
Table B1. U-Pb isotopic data for meta-igneous and igneous samples.

\begin{tabular}{|c|c|c|c|c|c|c|c|c|c|c|c|c|c|c|c|c|}
\hline \multirow[b]{2}{*}{ Sample } & \multirow[b]{2}{*}{ Fraction } & \multicolumn{10}{|c|}{ Isotopic ratios } & \multicolumn{5}{|c|}{ Apparent age $(\mathrm{Ma})$ summary } \\
\hline & & $\begin{array}{l}\text { Weight } \\
\text { (mg) }\end{array}$ & $\begin{array}{c}\mathrm{U} \\
(\mathrm{ppm})\end{array}$ & $\begin{array}{c}\text { Th/ } \\
\mathrm{U}\end{array}$ & $\begin{array}{l}\text { total } \mathrm{Pb} \\
(\mathrm{pg})\end{array}$ & $\begin{array}{c}\text { common } \\
\mathrm{Pb}(\mathrm{pg})\end{array}$ & $\begin{array}{l}{ }^{206} \mathrm{~Pb} / \\
{ }^{204} \mathrm{~Pb}\end{array}$ & $\begin{array}{l}{ }^{206} \mathrm{~Pb} / \\
{ }^{238} \mathrm{U}\end{array}$ & $\pm 2 \sigma$ & $\begin{array}{l}{ }^{207} \mathrm{~Pb} / \\
{ }^{235} \mathrm{U}\end{array}$ & $\pm 2 \sigma$ & $\begin{array}{l}{ }^{206} \mathrm{~Pb} / \\
{ }^{238} \mathrm{U}\end{array}$ & $\pm 2 \sigma$ & $\begin{array}{l}{ }^{207} \mathrm{~Pb} / \\
{ }^{206} \mathrm{~Pb}\end{array}$ & $\pm 2 \sigma$ & $\begin{array}{l}\text { disc. } \\
(\%)\end{array}$ \\
\hline \multicolumn{17}{|c|}{ SMB02-81 Chuggin Road tonalitic orthogneiss } \\
\hline jk9p122 & $\mathrm{Z} 1$ clr 3:1 subh pr incl (1) & 0.0013 & 137 & 0.51 & 17.1 & 0.2 & 5097 & 0.0916 & 0.0004 & 0.742 & 0.004 & 564.9 & 2.4 & 559.3 & 9.2 & -1.0 \\
\hline jk9p123 & $\mathrm{Z} 2$ clr 3:1 subh pr (1) & 0.0017 & 228 & 0.60 & 37.7 & 0.5 & 4605 & 0.0906 & 0.0004 & 0.734 & 0.004 & 558.9 & 2.5 & 558.9 & 7.2 & 0.0 \\
\hline jk9p124 & Z3 clr 3:1 subh pr (1) & 0.0012 & 343 & 0.49 & 37.9 & 0.1 & 20104 & 0.0884 & 0.0004 & 0.718 & 0.003 & 546.2 & 2.3 & 562.9 & 4.7 & 3.1 \\
\hline jk9p125 & Z4 clr 3:1 subh pr (3) & 0.0020 & 121 & 0.72 & 24.4 & 0.2 & 7519 & 0.0911 & 0.0004 & 0.739 & 0.003 & 562.2 & 2.4 & 561.1 & 7.7 & -0.2 \\
\hline jk10p14 & Z5 clr eq subh pr (1) & 0.0063 & 133 & 1.10 & 153.1 & 0.3 & 31394 & 0.1506 & 0.0005 & 1.461 & 0.005 & 904.1 & 3.0 & 939.8 & 3.6 & 4.1 \\
\hline jk10p15 & Z6 clr eq mf euh pr (4) & 0.0052 & 89 & 0.31 & 73.4 & 0.2 & 29824 & 0.1572 & 0.0006 & 1.681 & 0.006 & 941.0 & 3.2 & 1136.3 & 4.2 & 18.5 \\
\hline \multicolumn{17}{|c|}{ SMB02-79 biotite granite, Creignish Hills pluton } \\
\hline jk9p73 & Z1 2:1 euh clr pr incl (1) & 0.0062 & 173 & 0.52 & 99.3 & 0.5 & 11557 & 0.0883 & 0.0005 & 0.714 & 0.004 & 545.8 & 3.1 & 551.4 & 4.2 & 1.1 \\
\hline jk9p74 & Z2 2:1 euh clr pr incl (1) & 0.0048 & 83 & 0.58 & 37.8 & 0.3 & 8404 & 0.0889 & 0.0004 & 0.720 & 0.003 & 549.2 & 2.2 & 555.4 & 6.9 & 1.2 \\
\hline jk9p75 & Z3 2:1 euh clr pr (2) & 0.0042 & 95 & 0.53 & 37.5 & 7.3 & 332 & 0.0897 & 0.0004 & 0.725 & 0.025 & 553.8 & 2.4 & 553.4 & 69.6 & -0.1 \\
\hline jk9p111 & Z4 2:1 euh clr pr (3) & 0.0076 & 77 & 0.63 & 54.1 & 0.2 & 21183 & 0.0888 & 0.0005 & 0.717 & 0.003 & 548.1 & 2.9 & 553.1 & 7.8 & 0.9 \\
\hline \multicolumn{17}{|c|}{ SMB02-83 biotite granite, West Bay pluton } \\
\hline jk9p76 & $\mathrm{Z} 1$ euh 2:1 clr pr incl (1) & 0.0057 & 104 & 0.51 & 55.0 & 0.4 & 9003 & 0.0889 & 0.0003 & 0.718 & 0.003 & 549.2 & 1.9 & 551.2 & 4.6 & 0.4 \\
\hline jk9p77 & $\mathrm{Z} 2$ euh 2:1 clr pr (2) & 0.0030 & 165 & 0.54 & 46.4 & 0.2 & 14458 & 0.0887 & 0.0003 & 0.718 & 0.002 & 548.5 & 1.7 & 554.2 & 3.9 & 1.2 \\
\hline jk9p78 & $\mathrm{Z} 3$ euh 2:1 clr pr (2) & 0.0030 & 197 & 0.51 & 54.9 & 0.2 & 14490 & 0.0887 & 0.0005 & 0.716 & 0.004 & 547.7 & 2.7 & 552.1 & 4.3 & 0.8 \\
\hline
\end{tabular}

Notes: Data are from abraded zircons (Krogh 1982). Decay constants used are those of Jaffey et al . (1971). Abbreviations: $Z=$ zircon; euh = euhedral; subh = subhedral; eq = equant; $\mathrm{pr}=$ prism; $\mathrm{clr}=$ colourless; $\mathrm{lbr}=$ light brown; $\mathrm{mf}=$ multifaceted; incl = inclusions; 2:1, 3:1, etc. = length:breadth ratio; Number in brackets indicates number of grains analysed. Th/U - based on radiogenic ${ }^{208} \mathrm{~Pb} /{ }^{206} \mathrm{~Pb}$ ratio and ${ }^{207} \mathrm{~Pb} /{ }^{206} \mathrm{~Pb}$ age. Common $\mathrm{Pb}$ - total common $\mathrm{Pb}$, blank isotopic composition: ${ }^{206} \mathrm{~Pb} /{ }^{204} \mathrm{~Pb}=18.221,{ }^{207} \mathrm{~Pb} /{ }^{204} \mathrm{~Pb}=15.612,{ }^{208} \mathrm{~Pb} /{ }^{204} \mathrm{~Pb}=39.36$. disc. (\%) = percent discordance for the given ${ }^{207} \mathrm{~Pb} /{ }^{206} \mathrm{~Pb}$ age.

22.5 nsec were employed for Daly detector measurements. A thermal source mass discrimination correction of $0.1 \%$ per atomic mass unit for both $\mathrm{Pb}$ and $\mathrm{U}$ was also used.

The assigned laboratory blank for $U$ is $0.2 \mathrm{pg}$. Total measured common $\mathrm{Pb}$ in samples was below $1 \mathrm{pg}$ in nearly all cases and was assigned the isotopic composition of the lab blank. Error estimates were calculated by propagating known sources of analytical uncertainty for each analysis including ratio variability (within run), uncertainty in the fractionation correction, and uncertainties in the isotopic composition of laboratory blank. Decay constants used are those of Jaffey et al. (1971). All uncertainties in the text below and on concordia diagrams are given at the $95 \%$ confidence level. Discordia lines and concordia intercept ages were calculated by the method of Davis (1982) using the in-house program ROMAGE. Average ${ }^{207} \mathrm{~Pb} /{ }^{206} \mathrm{~Pb}$ ages or ${ }^{206} \mathrm{~Pb} /{ }^{238} \mathrm{U}$ ages were also calculated using ROMAGE. Probability of fit measures the scatter of analyses with respect to a $\mathrm{Pb}$-loss line. A value of around $50 \%$ would be expected for unimodal data sets with correctly chosen analytical errors. Low probability of fit suggests real differences in $\mathrm{Pb}$ loss history and/or zircon crystallization age. Data are presented in Table B1.

\section{APPENDIX C}

Chips of sample SMB06-111 were crushed gently, then sieved and washed. Typically, about 20 muscovite grains or grain fragments $(\sim 0.3-1.0 \mathrm{~mm}$ in diameter) were handpicked from each sample. The selected grains were placed individually into holes machined in aluminum disks and then irradiated in the McMaster University nuclear reactor. The flux monitors were the hornblende standard, MMhb-1, and the sanidine standard, Fish Canyon tuff. An age of 525 Ma was used for the former and 28.2 Ma for the latter. The age of the Fish Canyon standard is the value proposed recently by Kuiper et al. (2008), and the age of MMhb-1 is the one obtained from intercalibration of the two standards in the Dalhousie laboratory. Our value for MMhb- 1 agrees with the ca. $526 \mathrm{Ma}$ age derived from the intercalibrations of Renne et al. (1998) and with the ca. $523 \mathrm{Ma}$ age suggested by Schoene and Bowring (2006) based on their U-Pb data on co-existing minerals. For whole-grain laser analysis, our Nd-YAG system was operated in the IR (at $1064 \mathrm{~nm}$ ). In continuous mode with the beam expanded to approximately cover the grain, power was increased in a series of steps until complete fusion was achieved. All isotopic analyses were made using a VG 3600 mass spectrometer. Data are presented in Table C1.

\section{APPENDIX D}

New analytical data are presented in Table D1, which also includes the analytical methods as footnotes. Sources of other chemical data are summarized in Table D2. 
Table C1. Total fusion data for muscovite grains in sample SMB06-111.

\begin{tabular}{|c|c|c|c|c|c|c|c|c|}
\hline spot & code\# & $\begin{array}{r}{ }^{39} \mathrm{Ar} \\
(\mathrm{mV})\end{array}$ & $\begin{array}{c}\% \\
\text { ATM } \\
\end{array}$ & $\begin{array}{l}{ }^{37} \mathrm{Ar} / \\
{ }^{39} \mathrm{Ar} \\
\end{array}$ & $\begin{array}{l}{ }^{36} \mathrm{Ar} / \\
{ }^{40} \mathrm{Ar} \\
\end{array}$ & $\begin{array}{l}{ }^{39} \mathrm{Ar} / \\
{ }^{40} \mathrm{Ar} \\
\end{array}$ & $\%$ IIC & $\begin{array}{c}\text { Age }(\mathrm{Ma}) \pm \\
1 \sigma\end{array}$ \\
\hline \multicolumn{9}{|c|}{$\mathrm{J}=0.0024 \pm 2.4 \mathrm{E}-05$} \\
\hline 1 & G56-01 & 4 & 14.9 & 0 & 0.00051 & 0.007 & 0 & $476.1 \pm 3.1$ \\
\hline 2 & G56-02 & 19.1 & 6.8 & 0 & 0.00023 & 0.008 & 0 & $458.7 \pm 2.5$ \\
\hline 3 & G56-03 & 11 & 8.7 & 0 & 0.0003 & 0.008 & 0 & $437.6 \pm 2.4$ \\
\hline 4 & G56-04 & 8.2 & 9 & 0 & 0.00031 & 0.007 & 0 & $462.4 \pm 2.5$ \\
\hline 5 & G56-05 & 11.4 & 8.4 & 0 & 0.00029 & 0.008 & 0 & $459.2 \pm 2.5$ \\
\hline 6 & G56-06 & 9.2 & 8.8 & 0 & 0.0003 & 0.008 & 0 & $445.0 \pm 2.3$ \\
\hline 7 & G56-07 & 8.6 & 9.1 & 0 & 0.00031 & 0.007 & 0 & $460.7 \pm 2.4$ \\
\hline 8 & G56-08 & 6.5 & 12 & 0 & 0.00041 & 0.007 & 0 & $456.4 \pm 2.6$ \\
\hline 9 & G56-09 & 12.3 & 7.6 & 0 & 0.00026 & 0.007 & 0 & $472.4 \pm 2.5$ \\
\hline 10 & G56-10 & 14.6 & 6.9 & 0 & 0.00023 & 0.008 & 0 & $457.6 \pm 2.4$ \\
\hline 11 & G56-11 & 11.8 & 8 & 0 & 0.00027 & 0.008 & 0 & $444.2 \pm 2.3$ \\
\hline 12 & G56-12 & 13.6 & 7.5 & 0 & 0.00026 & 0.008 & 0 & $429.6 \pm 2.2$ \\
\hline 13 & G56-13 & 12.8 & 6.9 & 0 & 0.00023 & 0.008 & 0 & $441.8 \pm 2.2$ \\
\hline 14 & G56-14 & 5.8 & 13.3 & 0 & 0.00045 & 0.008 & 0 & $438.1 \pm 2.6$ \\
\hline 15 & G56-15 & 8.3 & 9.5 & 0 & 0.00032 & 0.008 & 0 & $432.8 \pm 2.3$ \\
\hline 16 & G56-16 & 12.5 & 7.9 & 0 & 0.00027 & 0.008 & 0 & $449.6 \pm 2.4$ \\
\hline 17 & G56-17 & 6.1 & 12.2 & 0 & 0.00041 & 0.007 & 0 & $473.9 \pm 2.6$ \\
\hline 18 & G56-18 & 5.1 & 12.5 & 0 & 0.00043 & 0.007 & 0 & $487.8 \pm 2.8$ \\
\hline 19 & G56-19 & 6.5 & 11.1 & 0 & 0.00038 & 0.007 & 0 & $468.6 \pm 2.7$ \\
\hline 20 & G56-20 & 8.7 & 9.4 & 0 & 0.00032 & 0.007 & 0 & $476.1 \pm 2.6$ \\
\hline 21 & G56-21 & 10.6 & 7.9 & 0 & 0.00027 & 0.007 & 0 & $478.0 \pm 2.4$ \\
\hline 22 & G56-22 & 11.9 & 7.9 & 0 & 0.00027 & 0.008 & 0 & $449.4 \pm 2.3$ \\
\hline 23 & G56-23 & 15.4 & 5.9 & 0 & 0.0002 & 0.007 & 0 & $475.7 \pm 2.3$ \\
\hline
\end{tabular}

Notes: ${ }^{37} \mathrm{Ar} /{ }^{39} \mathrm{Ar},{ }^{36} \mathrm{Ar} /{ }^{40} \mathrm{Ar}$, and ${ }^{39} \mathrm{Ar} /{ }^{40} \mathrm{Ar}$ are corrected for mass spectrometer discrimination, interfering isotopes, and system blanks; \% IIC = interfering isotopes correction.
Table D1. Previously unpublished chemical data. ${ }^{* *}$

\begin{tabular}{|c|c|c|c|}
\hline Sample \# & SMB02-81a & SCGQ1 & SCGQ2 \\
\hline Unit & Chuggin Road & West Bay & West Bay \\
\hline $\mathrm{N}$ & 5094125 & $5063307^{\star}$ & $5063307^{\star}$ \\
\hline $\mathrm{E}$ & 642350 & $631658^{*}$ & $631658^{*}$ \\
\hline $\mathrm{SiO}_{2}$ (wt.\%) & 67.92 & 74.82 & 71.93 \\
\hline $\mathrm{TiO}_{2}$ & 0.443 & 0.24 & 0.36 \\
\hline $\mathrm{Al}_{2} \mathrm{O}_{3}$ & 15.08 & 12.7 & 13.76 \\
\hline $\mathrm{Fe}_{2} \mathrm{O}_{3}$ & 4.68 & 1.3 & 2.75 \\
\hline $\mathrm{MnO}$ & 0.066 & 0.02 & 0.06 \\
\hline $\mathrm{MgO}$ & 1.71 & 0.13 & 0.65 \\
\hline $\mathrm{CaO}$ & 4.42 & 0.13 & 1.21 \\
\hline $\mathrm{Na}_{2} \mathrm{O}$ & 2.89 & 2.33 & 3.12 \\
\hline $\mathrm{K}_{2} \mathrm{O}$ & 1.57 & 5.36 & 4.64 \\
\hline $\mathrm{P}_{2} \mathrm{O}_{5}$ & 0.143 & 0.06 & 0.1 \\
\hline LOI & 0.95 & 1.5 & 1.1 \\
\hline Total & 99.87 & 98.59 & 99.68 \\
\hline $\mathrm{Ba}(\mathrm{ppm})$ & 497 & 222 & 453 \\
\hline $\mathrm{Rb}$ & 59 & 218 & 206 \\
\hline $\mathrm{Sr}$ & 357 & 32 & 130 \\
\hline Y & 15 & 38 & 60 \\
\hline $\mathrm{Zr}$ & 151 & 178 & 197 \\
\hline $\mathrm{Nb}$ & 12 & 14 & 18 \\
\hline Th & 3 & 29 & 22 \\
\hline $\mathrm{Pb}$ & 9 & 18 & 31 \\
\hline $\mathrm{Ga}$ & 15 & 14 & 15 \\
\hline $\mathrm{Zn}$ & 49 & 17 & 60 \\
\hline $\mathrm{Cu}$ & 63 & 5 & 5 \\
\hline $\mathrm{Ni}$ & $<3$ & 5 & 7 \\
\hline V & 91 & 7 & 26 \\
\hline $\mathrm{Cr}$ & 8 & 6 & 7 \\
\hline
\end{tabular}

Notes: Sample locations are UTMs (N, northing; E, easting) in Grid Zone 20T, NAD83. ${ }^{\star}$ Location estimated from Google Earth. ${ }^{* *}$ Analyses by X-ray fluorescence at the Regional Geochemical Centre, Saint Mary's University, Halifax, Nova Scotia. Major elements and some trace elements were measured using fused glass disks and other trace elements were measured using pressed powder pellets. Analytical error is generally less than $5 \%$ for major elements and $2-10 \%$ for trace elements. $\mathrm{Fe}_{2} \mathrm{O}_{3}{ }^{\mathrm{t}}$ is total $\mathrm{Fe}$ as $\mathrm{Fe}_{2} \mathrm{O}_{3}$. LOI is loss on ignition at $1000^{\circ} \mathrm{C}$. 
Table D2. Sources of chemical data for plutonic units. Data sources are in reference list.

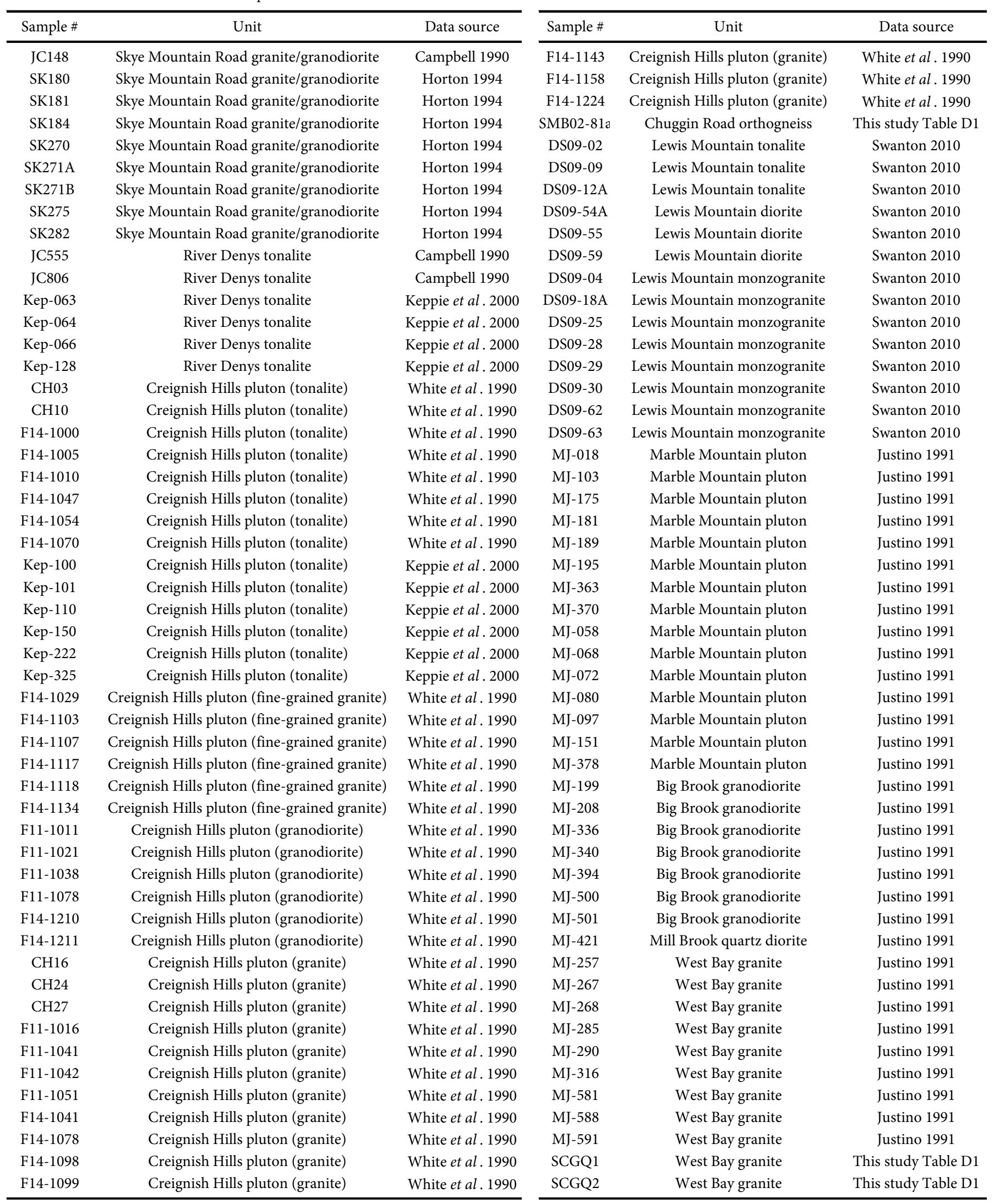

